\title{
Utjecaj starenja stanovništva na javne financije u Europskoj uniji
}

Žokalj, Mateo

Source / Izvornik: Odabrani prijevodi, 2016, 7, 1 - 24

Journal article, Published version

Rad u časopisu, Objavljena verzija rada (izdavačev PDF)

https://doi.org/10.3326/op.44

Permanent link / Trajna poveznica: https://urn.nsk.hr/urn:nbn:hr:242:546421

Rights / Prava: Attribution-NonCommercial-NoDerivatives 4.0 International/ImenovanjeNekomercijalno-Bez prerada 4.0 međunarodna

Download date / Datum preuzimanja: 2023-04-26

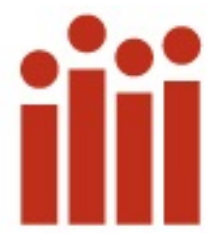

Institute of Public Finance Repository

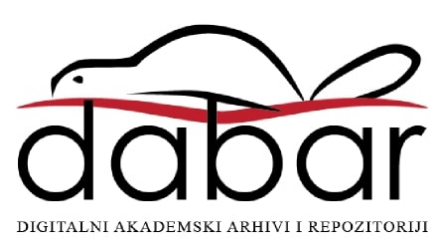


Institut za

javne financije

Smičiklasova 21 | Zagreb

www.ijf.hr | ured@ijf.hr

T: 01/4886-444 | F: 01/4819-365

ODABRANI

PRIJEVODI

\section{BR. 44}

\section{6.}

ISSN 1847-7445

citirati: Žokalj, M., 2016. The impact of population aging on public finance in the European Union. Financial Theory and Practice, 40 (4), str. 383-412. Dostupno na: < http://www.fintp.hr/upload/files/ftp/2016/4/zokalj.pdf>

Svi Odabrani prijevodi dostupni su na:

http://www.ijf.hr/hr/publikacije/casopi si/12/odabrani-prijevodi/111/

\section{UTJECAJ STARENJA STANOVNIŠTVA NA JAVNE FINANCIJE U EUROPSKOJ UNIJI}

\author{
MATeO ŽoKALJ, univ.bacc.oec. ${ }^{*} \quad$ Preliminarna KomUnikACIJA* \\ JEL: J14, H5, H6, E62 \\ DOI: $10.3326 /$ op. 44
}

\section{SAŽETAK}

Starenje stanovništva utječe na gospodarstva većine razvijenih zemalja svijeta te bi razumijevanje odnosa javnih financija i demografskih varijabli omogućilo prilagodbe i poboljšanja srednjoročnih proračunskih okvira. Cilj je ovog rada istražiti fiskalni utjecaj starenja stanovništva koristeći panel podatke 25 zemalja EU-a u razdoblju od 1995. do 2014. Kako bi se unaprijedili dosadašnji empirijski rezultati, u modelu se endogeniziraju demografske varijable te se primjenjuje sistemski procjenitelj generalizirane metode momenata (GMM) za utvrđivanje elastičnosti fiskalnih varijabli s obzirom na starenje stanovništva. Rezultati ukazuju na pozitivan utjecaj starenja stanovništva na izdatke za mirovine i socijalnu zaštitu. Jači pozitivan utjecaj na proračunske rashode nego prihode potvrđuje negativan utjecaj starenja stanovništva na deficit proračuna. Veliki broj mladih stanovnika značajno utječe samo na izdatke za zdravstvo.

Ključne riječi: starenje stanovništva, demografska tranzicija, javne financije, sistemski GMM

\footnotetext{
* Autor zahvaljuje prof. Teodosiu Pérez Amaralu i prof. Juanu Gabrielu Rodríguez Hernándezu na njihovoj pomoći tijekom pisanja rada, kao i dvojici anonimnih recenzenata na korisnim komentarima. Za sve preostale greške odgovoran je autor.

** Primljeno: 01. lipnja 2016.

Prihvaćeno: 03. studenoga 2016.
}

Članak je osvojio nagradu u kategoriji studentskih radova zaklade Prof. dr. Marijan Hanžeković za 2016. godinu.

Mateo ŽOKALJ

Sveučilište u Zagrebu, Ekonomski fakultet, Trg J. F. Kennedya 6, 10000 Zagreb

email: mateozokalj93@gmail.com 


\section{UvOD}

Usprkos značajnom utjecaju financijske krize ${ }^{1}$ na svjetsku ekonomiju, demografska tranzicija je jedan od najvećih predstojećih izazova EU-a i ostalih razvijenih zemalja. Baby boom, koji se u Europi odvijao u razdoblju od 1950-ih do 1970-ih, i kasniji pad stope fertiliteta popraćen produljenjem životnog vijeka, doveli su do značajnih promjena u dobnoj strukturi ukupnog stanovništva. Posljedično, državni proračuni i ostale makroekonomske varijable su već pod utjecajem ovog strukturnog pomaka. Ekonomska kriza naglasila je i potvrdila značaj fiskalne politike u prevenciji i ublažavanju kratkoročnih ekonomskih fluktuacija, no utjecaj starenja stanovništva na javne financije se i dalje (nepravedno) zanemaruje. U nadolazećim desetljećima, demografska tranzicija će preoblikovati gospodarstva i u razvijenim zemljama i u zemljama u razvoju.

Demografske promjene će mijenjati veličine i strukture proračunskih prihoda i rashoda. Za dugoročnu održivost trenutačnih modela države blagostanja prevladavajućih u većini zemalja EUa, neophodne su strukturne promjene u zakonskom i poreznom sustavu. Uz rastući udio starijeg stanovništva, sadašnja i buduća radna snaga može očekivati povećanje poreza na dohodak i indirektnih poreza, poput PDV-a i trošarina, a sve će značajnije biti i oporezivanje kapitala (porez na dividendu, kapitalnu dobit i nekretnine). Zaključno, oporezivanje rada i kapitala bi se moglo mijenjati usporedno s demografskom tranzicijom.

Ključna promjena u proračunskim rashodima vezana uz dob očekuje se u izdacima poput mirovina, zdravstvene skrbi i dugoročne njege. Posredno, povećanje starijeg stanovništva utječe i na ostale kategorije proračunskih rashoda poput izdataka za obrazovanje. Očekuje se da će povećanje starije dobne skupine, zbog manjeg broja učenika, dovesti u pitanje sadašnju razinu izdataka za obrazovanje. Osim toga, zbog izdataka za socijalnu zaštitu mogu se smanjiti javne investicije. S druge strane, malo je vjerojatno da će veličina i struktura proračunskih prihoda ostati nepromijenjena. Prihodi od PDV-a su pod utjecajem promjena u ponašanju potrošača, dok su prihodi od poreza na dohodak uvjetovani i promjenama na tržištu rada.

Cilj ovog istraživanja je procjena utjecaja starenja stanovništva na javne financije u 25 članica EU$\mathrm{a}^{2}$ od 1995. do 2014. Koristeći četverogodišnje uprosječene intervale, analizira se srednjoročna dinamika korigirana za kratkoročne fluktuacije. Statički model korišten u Callen et al. (2004.) i Yoon et al. (2014) proširen je uvođenjem lagirane vrijednosti zavisne varijable te dodavanjem kontrolnih varijabli. Prijašnja istraživanja, koja su uključivala demografske varijable, smatrala su demografske promjene egzogenima, odbacujući mogućnost dvosmjerne uzročnosti između fiskalnih i demografskih varijabli. Kako bi se poboljšali dosadašnji rezultati, u modelu se endogeniziraju demografske varijable. Koristeći robustan jednofazni sistemski procjenitelj generalizirane metode momenata (GMM), analiza podataka ukazuje da starenje stanovništva utječe na rast izdataka za mirovine, socijalnu zaštitu te ukupne proračunske prihode i rashode. Ukupni učinak na proračunski saldo je negativan zbog većeg procijenjenog koeficijenta vezanog uz proračunske rashode. S druge strane, povećanje udjela mladog stanovništva ima značajan učinak samo na rast izdataka za zdravstvo.

\footnotetext{
${ }^{1}$ Financijska kriza koja je započela bankrotom Lehman Brothersa 2008.

2 Belgija, Bugarska, Češka Republika, Danska, Njemačka, Estonija, Irska, Latvija, Litva, Švedska, Finska, Ujedinjeno Kraljevstvo, Rumunjska, Hrvatska, Slovenija, Slovačka, Poljska, Mađarska, Italija, Austrija, Francuska, Španjolska, Cipar, Portugal i Nizozemska.
} 
Glavno istraživačko pitanje je utječe li starenje stanovništva na proračunske kategorije, kao i na ukupni proračunski saldo, nakon endogenizacije demografskih varijabli. Hipoteza predviđa pozitivan učinak na sve proračunske kategorije, time slijedeći rezultate dosadašnjih istraživanja, no uz preciznije procjene zahvaljujući korištenju naprednije metodologije.

Nakon uvoda, u drugom se dijelu nude demografski trendovi i prognoze za odabrane zemlje EU-a, u trećem projekcije proračunskih rashoda, u četvrtom teoretski okvir koji uspostavlja opću ravnotežu s uključenom demografskom komponentom, u petom pregled empirijskih rezultata postojeće literature o utjecaju starenja stanovništva na javne financije i ekonomiju, u šestom empirijska analiza koja sadrži metodologiju, deskriptivnu analizu te empirijski model i rezultate, u sedmom zaključna razmatranja.

\section{DEMOGRAFSKI TRENDOVI I PROJEKCIJE}

Kao u ostalim razvijenim zemljama, stanovništvo EU-a je promijenilo dobnu strukturu: udio starijeg stanovništva se povećava uz istovremeno smanjenje udjela mlade populacije. Međutim, sadašnje starenje stanovništva je rezultat prijašnjih promjena fertiliteta, mortaliteta i migracija. Stoga se u ovom poglavlju prikazuju projekcije demografskih odrednica starenja stanovništva.

Eurostat je 2014. na temelju kretanja ključnih demografskih varijabli - stope fertiliteta, očekivanog životnog vijeka i migracijskih tokova - objavio demografske projekcije "EUROPOP13" za razdoblje od 2013. do 2060. Metodologija se temelji na pristupu koji pretpostavlja konvergenciju demografskih odrednica unutar zemalja EU-a. Očekuje se da će broj stanovnika od 2013. do 2050. narasti s 507 na 526 milijuna, te se zatim smanjiti na 523 milijuna 2060. Unutar EU-a, kretanje broja stanovnika je neujednačeno te će 2060. otprilike polovica zemalja imati manje stanovnika nego 2013.

Stopa totalnog fertiliteta (STF) je prosječan broj djece koje bi žena mogla roditi u svom fertilnom razdoblju (pod uvjetom da doživi kraj tog razdoblja) ako bi rađala djecu u skladu s dobnospecifičnim stopama fertiliteta $\mathrm{u}$ danoj godini. Rast STF-a se predviđa u svim promatranim zemljama, osim u Francuskoj, Švedskoj i Irskoj, dok će stagnirati u Ujedinjenom Kraljevstvu. Na agregatnoj razini, prosječni STF će narasti s 1,59 u 2013. na 1,76 u 2060., što je ispod razine od 2,1 koja osigurava zamjenu generacija.

U svim se članicama EU-a očekuje produljenje očekivanog životnog vijeka pri rođenju, uz najveći rast u zemljama s najkraćim životnim vijekom 2013. (zemlje Baltika, Rumunjska, Bugarska i Mađarska). Na razini EU-a, predviđeno trajanje života muškaraca će porasti sa 77,6 (2013.) na 84 godine života (2060.), a očekivani životni vijek žena 2060. iznosit će 89,1 godinu života (2013. je iznosio 83,1). Međutim, kretanje očekivanog trajanja života je predmet rasprave među demografima, jer buduća medicinska otkrića, promjene u društvenom ponašanju (prevencija pretilosti i pušenja) te dugoročni učinak javnih zdravstvenih programa mogu utjecati na točnost prognoza. Stoga se smatra da bi utjecaj starenja stanovništva na proračun mogao biti podcijenjen.

Očekuje se da će EU do 2060. zadržati i pozitivne neto migracijske tokove. Broj imigranata će se povećati s 874.000 (2013.) na 1,07 milijuna u 2060. dosežući vrhunac 2040., a glavna imigracijska odredišta će biti Španjolska, Italija, Njemačka i Ujedinjeno Kraljevstvo. Migracije su, međutim, osjetljive na političke i ekonomske šokove te ih je teško prognozirati. Optimistične ekonomske projekcije iz 2013. i izostavljanje masovne političke imigracije uzrokovane sukobima na Bliskom 
Istoku i u Africi mogu rezultirati podcijenjenim brojkama za imigraciju i emigraciju. Kada je Eurostat 2013. sastavljao demografske projekcije za narednih pedesetak godina, nije mogao računati s izbjegličkom krizom 2015. Također, asimetrični šokovi poput onih iz nedavne ekonomske krize prouzrokovali su migracije stanovništva iz mediteranskih zemalja te zemalja Srednje i Istočne Europe u sjeverne zemlje EU-a.

Stopa totalnog fertiliteta, očekivani životni vijek i migracijski tokovi su ključni demografski pokazatelji te se smatraju glavnim pokretačima starenja stanovništva. Rezultat tog procesa prikazan je stoga pomoću koeficijenata dobne ovisnosti, koji su u fokusu ovog istraživanja. Promjene prethodno navedenih pokazatelja utječu na gospodarstvo s pomakom od nekoliko desetljeća, no varijacije koeficijenata ovisnosti na ekonomiju utječu i ranije.

\section{GRAFIKON 1.}

Projekcije koeficijenta dobne ovisnosti starog stanovništva (u \%)

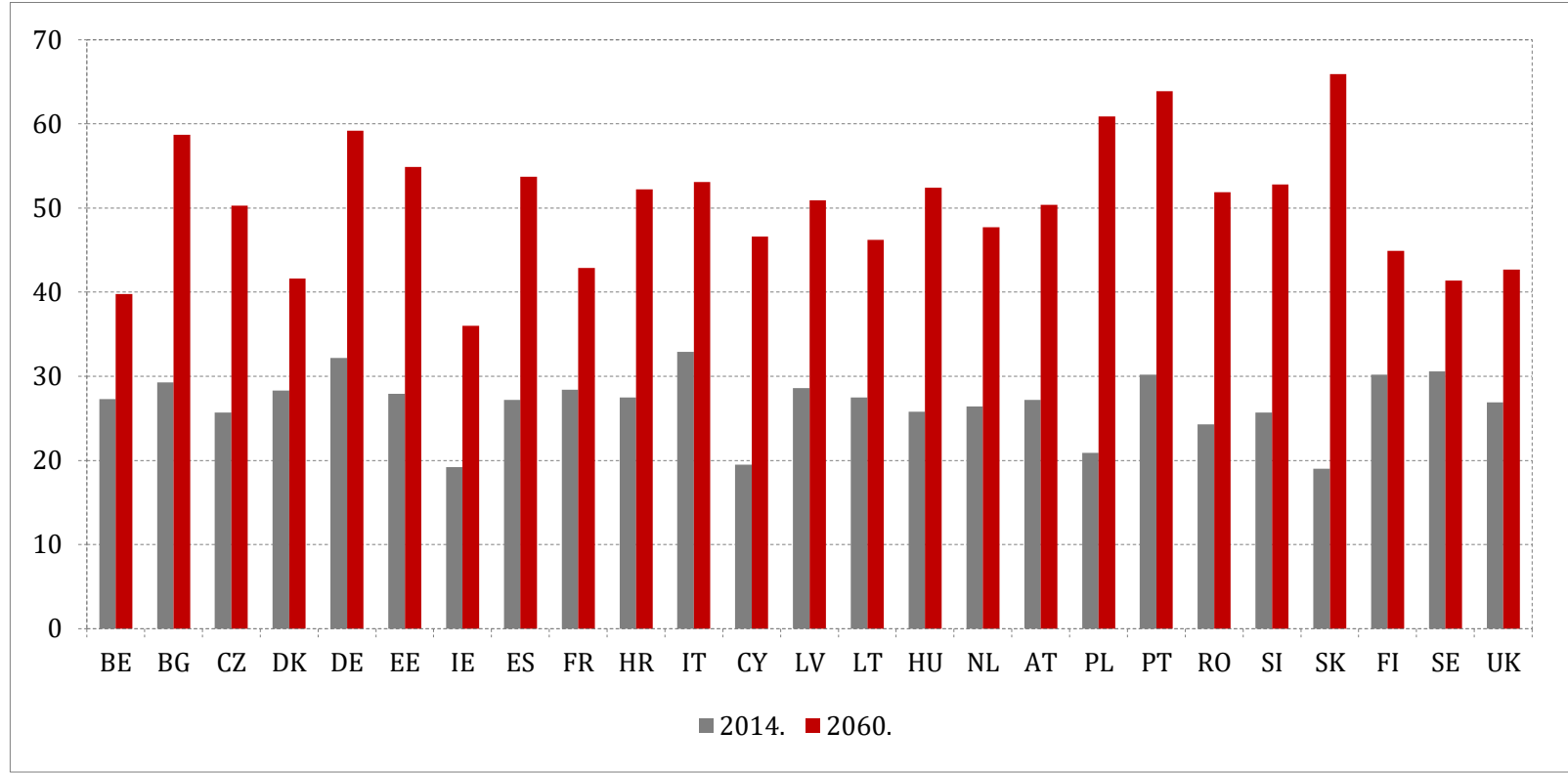

Izvor: Eurostat, 2014.

Koeficijent dobne ovisnosti starih (KDOS) je omjer stanovništva starijeg od 65 godina i radno sposobne populacije od 15. do 64. godine života. Grafikon 1 prikazuje projekcije KDOS-a za 2014. i 2060. s očekivanjem prosječnog povećanja od 93\%. Prosječan KDOS bi s 26,7 trebao narasti na 50,4, što znači da će na svaku osobu stariju od 64 godine biti otprilike dvije osobe u radno-sposobnoj dobi. Najveći će rast doživjeti Slovačka (269\%), a najmanji Švedska (35\%).

Koeficijent dobne ovisnosti mladih (KDOM) je omjer stanovništva do 14. godine života i radno sposobne populacije. Kao što je prikazano u grafikonu 2, u svim zemljama će KDOM narasti u prosjeku 13\%, osim u Portugalu i Irskoj gdje se prognozira smanjenje za 5,5\% i 7,13\%. Na agregatnoj razini, prosječni KDOM će narasti s 23,7 na 26,7, što znači da će ostati relativno konstantan sa četiri osobe u radno sposobnoj dobi na jedno dijete tijekom cijelog vremena. 


\section{GRAFIKON 2.}

Projekcije koeficijenta dobne ovisnosti mladog stanovništva (u \%)

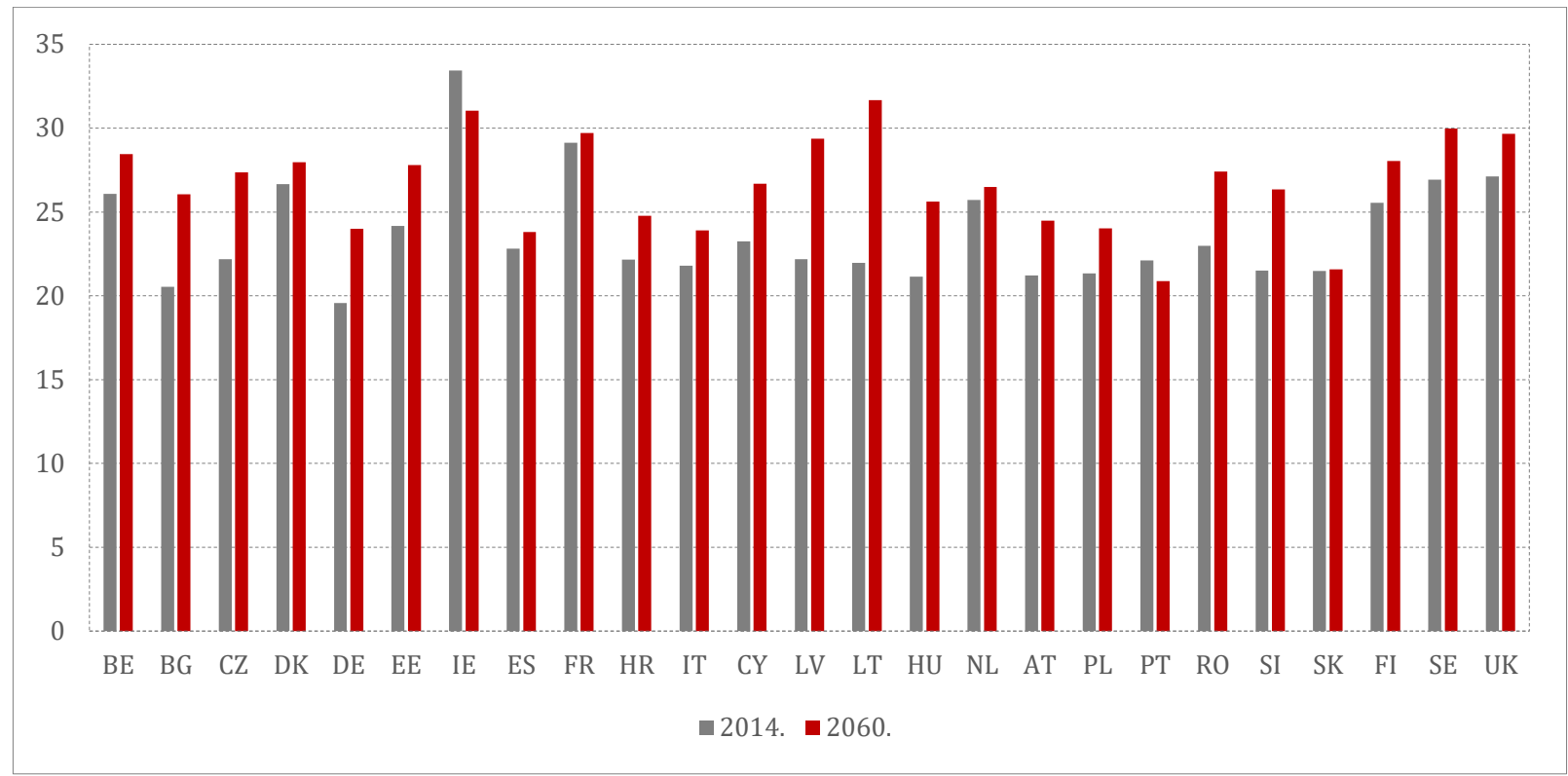

Izvor: Eurostat, 2014.

\section{PROJEKCIJE PRORAČUNSKIH RASHODA}

Europska komisija (2015.) je objavila projekcije za proračunske rashode, među ostalima i za mirovine te zdravstvenu skrb, na temelju demografskih projekcija EUROPOP13 (Eurostat, 2014.). Projekcije bruto rashoda za javne mirovine, u postotku BDP-a, su prikazane na grafikonu 3. Prosječni rashodi za javne mirovine će narasti s 10,3\% u 2013. na 10,5\% u 2060., no u nekim zemljama se očekuje rast, u drugima smanjenje. Najveće povećanje će zabilježiti Irska i Litva (35,1\% i 30,6\%), dok se zamjetni pad izdataka za mirovine očekuje u Latviji i Hrvatskoj (29,9\% te $27,8 \%$ ). No, kretanje javnih izdataka za mirovine u te dvije zemlje rezultat je promjena parametara u sustavu mirovina, a ne demografskih faktora.

Neočekivani rast izdataka za javne mirovine može se objasniti s četiri vrste učinaka: koeficijenta dobne zavisnosti starih, omjera pokrivenosti, omjera mirovinskih primanja te tržišta rada. Prema podatcima Europske komisije (2015.), rast KDOS-a je glavni pokretač povećanja javnih izdataka za mirovine, te je njegov doprinos veći od ukupne promjene izdataka u promatranom razdoblju. Na razini EU-a, učinak koeficijenta dobne zavisnosti starih povećava javne izdatke za mirovine za 7,2 postotna boda BDP-a, no gotovo u potpunosti se poništava zahvaljujući ostalim učincima. Omjer pokrivenosti definira se kao udio svih primatelja mirovina u populaciji starijoj od 65 godina. Uz iznimku Švedske, u svim zemljama se predviđa smanjenje omjera pokrivenosti, ponajprije zahvaljujući reformama u javnim mirovinskim sustavima (povećanjem dobne granice za ulazak u mirovinu, strožim kriterijima za dobivanje prijevremene mirovine te poticanjem dužeg ostanka na tržištu rada). Učinak tržišta rada negativno utječe na javne izdatke za mirovine, no mjere ciljane na povećanja ponude rada rezultiraju boljom održivosti mirovinskih sustava. Na kraju, omjer mirovinskih primanja računa se kao omjer prosječne mirovine i prosječne neto plaće, te pokazuje izdašnost mirovinskog sustava. Mjere poput cjenovne indeksacije smanjuju učinak omjera mirovinskih primanja, a u svim zemljama EU-a učinak omjera mirovinskih primanja će smanjiti razinu izdataka za mirovine. 
GRAFIKON 3.

Projekcije proračunskih izdataka za mirovine ( $\mathrm{u} \%$ BDP-a)

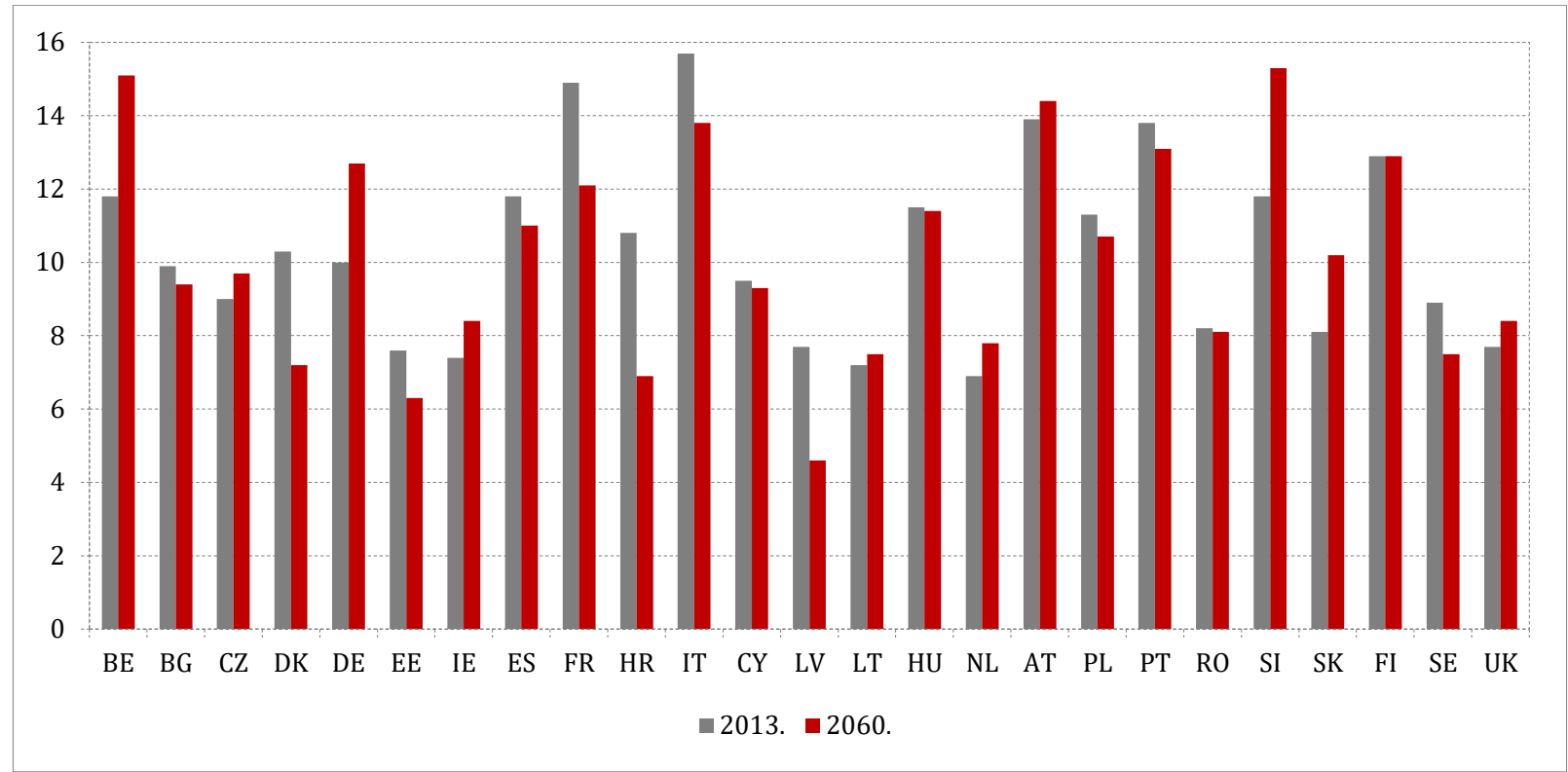

Izvor: Europska komisija, 2015.

Osim na javne izdatke za mirovine, očekuje se utjecaj starenja stanovništva i na proračunske izdatke za zdravstvenu skrb, no razina izdataka ovisi o ponudi i potražnji za zdravstvenim dobrima i uslugama. Potražnja je određena strukturom i zdravstvenim stanjem stanovništva te razinom individualnog i agregatnog dohotka, dok ponudu određuje tehnološki napredak, dostupnost zdravstvenih usluga i institucionalni okvir. Projekcije Europske komisije (2015.) za izdatke za zdravstvenu skrb sadrže više scenarija koji simuliraju različite promjene u prethodno navedenim odrednicama ponude i potražnje.

\section{GRAFIKON 4.}

Projekcije javnih izdataka za zdravstvenu skrb u scenariju dohodovne elastičnosti ( $\mathrm{\%} \%$ BDP-a)

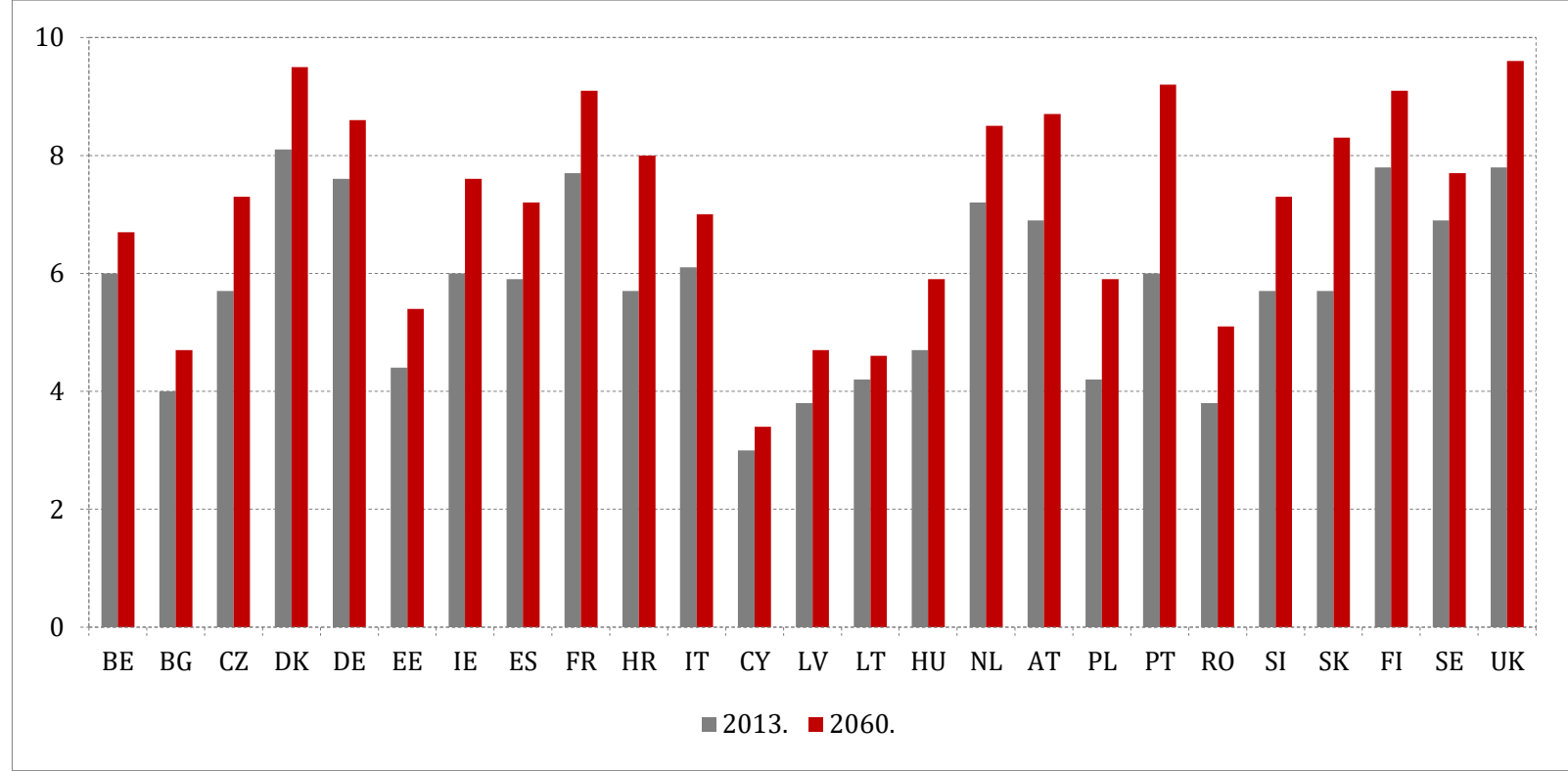

Izvor: Europska komisija, 2015. 
Demografski scenarij prikazuje učinak starenja stanovništva na izdatke za zdravstvenu skrb, no pretpostavlja da potrošnja za zdravstvenu skrb po stanovniku raste linearno s BDP-om po stanovniku što bi moglo dovesti do podcjenjivanja razine izdataka. Stoga, grafikon 4 predstavlja projekcije izdataka u "scenariju dohodovne elastičnosti" koji pretpostavlja dohodovnu elastičnost veću od 1 što karakterizira zdravstvenu skrb kao luksuzno dobro.

Grafikon 4 prikazuje kretanje javnih izdataka za zdravstvenu skrb od 2013. do 2060. u scenariju dohodovne elastičnosti. Očekuje se prosječan rast od 24\%, s najvećim porastom u Portugalu i Slovačkoj ( 53,3\% i 45,6\%), te najmanjim u Litvi $(9,5 \%)$.

\section{TEORIJSKI OKVIR}

Auerbach i Kotlikoff (1987.) razvojem su modela preklapajućih generacija u općoj dinamičkoj ravnoteži za zatvorenu ekonomiju prvi uključili demografsku komponentu u fiskalnu politiku. U modifikaciji prijašnjeg modela, Auerbach i Kotlikoff (1989.) uvode međunarodnu trgovinu, motive nasljedstva, tehnološku promjenu te javne izdatke koji ovise o dobnoj strukturi stanovništva. Nakon njih su mnogi autori simulirali modele opće ravnoteže sa specifičnim parametrima (ovisno o državi) temeljene na modelu preklapajućih generacija za malo otvoreno gospodarstvo (BörschSupan et al., 2006.; Jimeno et al., 2008.; Kudrna et al., 2015.). Slijedi kratki opis modela preklapajućih generacija za malo otvoreno gospodarstvo.

Svako je gospodarstvo pod utjecajem kućanstava, poduzeća, javnog sektora i međunarodnog okruženja. Sektor kućanstva se sastoji od 75 preklapajućih generacija s djecom (od 1. do 20. godine života) i odraslima (od 21. do 75. godine života). Svake godine, novorođena generacija zamjenjuje posljednju umiruću generaciju. U 21. godini života, dijete postaje odrasla osoba neovisna od roditeljske skrbi te postaje roditelj s egzogeno danim brojem djece koje uzdržava od svoje 21. do 41. godine. Pojedinci iste dobne skupine imaju identične sklonosti i savršeno predviđaju budućnost. Životna funkcija korisnosti odrasle osobe je zbroj njegove korisnosti, temeljene na sadašnjoj i budućoj vrijednosti potrošnje i odmora, korisnosti njegove djece i nasljedstva po djetetu (motivi nasljedstva) podijeljenog jednako među svim potomcima u zadnjoj godini života. Maksimizacija životne korisnosti odrasle osobe uz životno proračunsko ograničenje rezultira optimalnim vrijednostima potrošnje, odmora i motiva nasljedstva.

Sektor poduzeća čini reprezentativno proizvodno poduzeće koje djeluje u uvjetima savršene konkurencije. Proizvodnja je predstavljena Cobb-Douglasovom funkcijom uz konstantne prinose te homogene inpute (rad i kapital). Poduzeća maksimiziraju funkciju profita minimiziranjem izdataka za nadnice i rentu koje se uspostavljaju na tržištima inputa.

Javni sektor se sastoji od fiskalne vlasti i sustava socijalne zaštite. Fiskalnu vlast čine četiri kategorije proračunskih izdataka, od čega jedna nije dobno-povezana (primjerice izdaci za vojsku) dok su preostale kategorije namijenjene trima dobnim skupinama (1-24, 25-64 i 65+). Sustav socijalne zaštite posluje s uravnoteženim proračunom te uključuje socijalne naknade financirane porezom na dohodak. Međuvremensko proračunsko ograničenje zahtijeva jednakost sadašnje vrijednosti izdataka i javnog duga te poreznih prihoda.

Pretpostavka otvorene ekonomije predviđa uspostavljanje nadnica i kamatnih stopa na svjetskom tržištu i omogućuje razlikovanje vrijednosti imovine u gospodarstvu i domaće štednje. Ako je domaća štednja niža od vrijednosti imovine u gospodarstvu, zemlja je neto dužnik te ima negativan 
tekući račun platne bilance. Međutim, Miles (1999.) tvrdi kako je kamatna stopa endogena i u modelu male otvorene ekonomije, jer je starenje stanovništva prisutno u svim razvijenim zemljama.

Opća ravnoteža se uspostavlja kada svi ekonomski agenti djeluju u skladu sa sadašnjim i budućim ravnotežnim cijenama. Pretpostavka racionalnosti ekonomskih agenata omogućuje povezivanje sadašnje i buduće ekonomije. Kućanstva odabiru optimalnu kombinaciju rada i potrošnje, dok poduzeća odlučuju o investicijama na temelju budućeg kretanja nadnica i kamatnih stopa. Državna potrošnja mora zadovoljiti međuvremensko proračunsko ograničenje.

Drugačiji teorijski okvir predlaže Blanchard (1985.) koji zagovara model opće ravnoteže u uvjetima nesavršene konkurencije. Prednost tog pristupa je fleksibilnija struktura stanovništva i uvođenje neizvjesnosti trajanja života što omogućuje da se u model uključi i tržište osiguranja. Nedostatak Blanchardovog modela je, međutim, izjednačavanje granične sklonosti potrošnje međugeneracijskog bogatstva uz izostavljanje razlika u imovinskom vlasništvu kao posljedica nejednake ostavštine. Empirijska istraživanja poput Heijdra i Romp (2009.) i De la Croix et al. (2013.) slijede Blanchardov model.

\section{PREgled literature}

\subsection{UTJECAJ STARENJA STANOVNIŠTVA NA EKONOMSKI RAST I INFLACIJU}

Osim na javne financije, povećanje udjela starijeg stanovništva - kroz tržište rada i štednju - utječe na inflaciju i BDP po stanovniku. Ekonomisti raspravljaju o korelaciji ekonomskog rasta i starenja stanovništva, jer rezultati prijašnjih istraživanja ovise o korištenom modelu rasta (egzogeni ili endogeni) te ostalim bihevioralnim i računovodstvenim učincima. Koristeći Romerov endogeni model rasta (Romer, 1990.), Prettner (1995.) pronalazi pozitivni utjecaj starenja stanovništva na rast dohotka po stanovniku, dok u polu-endogenom modelu rasta (Jones, 1995.) tvrdi da taj učinak ovisi o tome radi li se o promjenama fertiliteta ili smrtnosti.

Hviding i Mérette (1998.) koristeći egozgeni model rasta utvrđuju negativan učinak starenja stanovništva, dok Fougère i Mérette (1999.) proširuju prethodno istraživanje koristeći endogeni model rasta pokazujući kako pozitivan učinak starenja stanovništva na ekonomski rast djeluje kroz povećana ulaganja u ljudski kapital. Bloom et al. (2011.) tvrde kako starenje stanovništva "predstavlja veliki, ali ne i nepremostivi izazov". Pritom razlikuju računovodstvene učinke, unutar kojih je dobno-specifični odnos naspram štednje i ponude rada fiksan, te bihevioralne učinke kada se potrošački obrazac, štednja i stopa aktivnosti mijenjaju usporedno s demografskom tranzicijom. U prvotnom se slučaju, zbog smanjenja ponude rada, predviđa blagi pad rasta dohotka po stanovniku u zemljama OECD-a. Međutim, uzimajući u obzir bihevioralne učinke koji produljuju radni vijek i povećavaju štednju, nepovoljni učinci starenja stanovništva mogu se poništiti. Nejasni neto učinak starenja stanovništva zahvaljujući bihevioralnim učincima potvrđuju Börsch-Supan et al. (2014.). Nadalje, Bussolo et al. (2015.) istražuju glavne pokretače i posljedice starenja stanovništva u Europi i srednjoj Aziji te zaključuju kako je ključni faktor starenja pad stope fertiliteta. Također, naglašavaju potencijalno pozitivan doprinos starenja zbog promjena ponašanja što bi moglo rezultirati manje apokaliptičnim ekonomskim posljedicama.

Nadalje, posljedice starenja na inflaciju nisu jednoglasno potvrđene s obzirom da Bullard et al. (2012.) i Shirakawa (2012.) smatraju kako su starije dobne skupine sklonije većoj štednji i nižoj 
inflaciji, dok Juselius i Takáts (2015.) prilažu empirijske dokaze u prilog rasta inflatornih pritisaka usporedno s povećanjem mlade i stare populacije. Katagiri et al. (2014.) dijele krajnji učinak starenja na inflaciju ovisno o uzroku. Starenje stanovništva uzrokuje deflatorne pritiske ako je potaknuto produljenjem životnog vijeka, a inflatorne ako je uzrokovano padom stope nataliteta.

\subsection{UTJECAJ STARENJA STANOVNIŠTVA NA JAVNE FINANCIJE}

Prema saznanju autora, jedno od prvih istraživanja povezanosti starenja stanovništva i javnih financija je Auerbach i Kotlikoff (1985.). Istražujući implikacije demografske tranzicije u SAD-u, autori predviđaju veliki rast stope poreza na dohodak, značajne promjene u sustavu socijalne zaštite te radikalne rezove socijalnih naknada. Auerbach et al. (1989.) dolaze do sličnih zaključaka analizirajući utjecaj starenja stanovništva u Japanu, Njemačkoj, Švedskoj i SAD-u koristeći prethodni model uz pretpostavku otvorene ekonomije. Yashiro et al. (1997.) razvijaju model opće ravnoteže za Japan kako bi se prikazale fiskalne implikacije starenja stanovništva i predložile neophodne reforme. Njihova analiza ukazuje na negativne učinke starenja stanovništva čime se potvrđuju rezultati prethodne literature. Díaz-Giménez i Díaz-Saavedra (2009.) koristeći model preklapajućih generacija kalibriran za Španjolsku predviđaju dugoročnu neodrživost mirovinskog sustava uz trenutačne demografske trendove.

Kudrna et al. (2015.) razrađuju model preklapajućih generacija za Australiju pod pretpostavkom male otvorene ekonomije s nestacionarnim demografskim trendovima. Kao rezultat porasta dobno-povezanih izdataka, predviđaju značajne promjene u ostalim kategorijama proračunskih izdataka i poreza radi ublažavanja učinaka demografskog pomaka. Zanimljivo je da u tom istraživanju isključuju potencijalna riješenja: povećanje stope fertiliteta i imigracije. King i Jackson (2000.) u empirijskom istraživanju za Kanadu zaključuju kako starenje stanovništva samo po sebi ne predstavlja veliki izazov za javne financije, no naglašavaju značaj smanjenja javnog duga u kratkom roku što bi omogućilo veći manevarski prostor u dugom roku.

Najveći broj radova o utjecaju starenja stanovništva na specifične kategorije proračunskih rashoda je iz područja ekonomike zdravstva. Chawla et al. (1998.) provode multivarijatnu analizu izdataka za zdravstvenu skrb na godišnjim podatcima za Poljsku od 1960. do 1995., te pronalaze slabu pozitivnu korelaciju populacije starije od 65 godina i povećanih izdataka za zdravstvo. Di Matteo i Di Matteo (1998.) koristeći združenu OLS regresiju za kanadske provincije pokazuju kako rast udjela starijeg stanovništva povećava u prosjeku za 1,3\% godišnje realne izdatke za zdravstvo po stanovniku. Di Matteo (2005.) proširuje prethodno istraživanje s podatcima za SAD na saveznoj razini te potvrđuje prijašnje rezultate. Međutim, kada se u model uključi trend komponentu, koja je proxy varijabla za tehnološki napredak, relativno manji udio izdataka za zdravstvo je objašnjen pomoću dobne distribucije stanovništva i dohotka po stanovniku.

Prieto i Lago-Peñas (2010.) tvrde kako specifikacija modela i ekonometrijska tehnika utječu na rezultate analize odrednica izdataka za zdravstvenu skrb. Analizirajući podatke za 17 španjolskih regija od 1992. do 2005., koristeći OLS regresiju i fiksne učinke, pronalaze dokaze pozitivnog učinka udjela starije populacije na izdatke za zdravstvo. Usprkos tome, upozoravaju na problem multikolinearnosti koji se javlja kada je uključeno više dobnih skupina. Kritički osvrt na literaturu o izdatcima za zdravstvo od 1998. do 2007. nude Martín et al. (2011.) gdje na uzorku od 20 studija, šest od njih izdvaja starenje stanovništva kao ključnu odrednicu izdataka. Međutim, zaključuju 
kako nema čvrstog empirijskog dokaza u prilog tezi kako je starenje stanovništva glavna odrednica, dok primjerice tehnološki napredak, približavanje smrti i teritorijalna decentralizacija postaju važni čimbenici u objašnjavanju razvoja izdataka za zdravstvo. Xu et al. (2011.) istražuju odrednice izdataka za zdravstvo u 143 zemlje (podijeljene u dohodovne skupine) u razdoblju od 1995. do 2008. uz pomoć statičkog modela s fiksnim učincima i dinamičkog modela sa sistemskim GMM procjeniteljem. U statičkom modelu, porast udjela starog stanovništva pozitivno utječe na rast samo u zemljama nižeg srednjeg dohotka, dok je u dinamičkom modelu za bilo koju dohodovnu grupu elastičnost starenja stanovništva nesignifikantna.

Lusky i Weinblatt (1998.) procjenjuju fiskalne učinke demografske promjene u 127 zemalja koristeći OLS regresiju te pronalaze dokaze pozitivnog i signifikantnog učinka porasta udjela starijeg stanovništva na udio javnih izdataka za zdravstvo. S druge strane, povećanje mladog i starijeg stanovništva dovodi do rasta izdataka za socijalnu zaštitu. Labrador i Angona (2003.) primjenjuju jednofazni diferencijski GMM procjenitelj u testiranju teorije medijanskog glasača u 26 zemalja OECD-a od 1970. do 1997. Povećanje udjela starijeg stanovništva smanjuje izdatke za javne usluge i stambeno zbrinjavanje, a povećava izdatke za zdravstvo i socijalnu zaštitu. Povećanje udjela mladog stanovništva dovodi do rasta izdataka za socijalnu zaštitu i obrazovanje te smanjuje izdatke za vojsku i ostale izdatke.

Callen et al. (2004.) istražuju utjecaj starenja stanovništva na nekoliko ekonomskih varijabli, među ostalima i na deficit proračuna. Koristeći regresiju s fiksnim učincima, ukazuju na negativnu povezanost povećanja udjela starijeg stanovništva i proračunskog salda na uzorku od 115 zemalja od 1960. do 2000. Yoon et al. (2014.) analizom podataka za zemlje OECD-a potvrđuju negativan učinak starenja stanovništva na proračunski saldo, s obzirom da povećanje starijeg stanovništva jače utječe na rast proračunskih rashoda nego prihoda. Hondroyiannis i Papapetrou (2008.) istražuju podatke za Grčku od 1960. do 1995. koristeći vektorski model korekcije pogreške. Pronalaze dokaze pozitivnog utjecaja starenja stanovništva na rast javnog duga i proračunske izdatke te negativnog na porezne prihode. S druge strane, Chen (2004.) dokazuje slab i negativan utjecaj starenja na proračunski saldo isključivo u zemljama u razvoju, dok u razvijenim zemljama taj proces smanjuje proračunski deficit.

\section{EMPIRIJSKA ANALIZA}

\subsection{PODATCI}

Istraživanje je provedeno na uzorku 25 članica EU-a, uz iznimku Grčke, Luksemburga i Malte. Grčka nije uključena zbog nedostatka (vjerodostojnih) statističkih podataka i ekonomske situacije, dok su Luksemburg i Malta isključeni zbog malog broja stanovnika. Vremenski niz se proteže od 1995. do 2014. s uprosječenim 4-godišnjim intervalima. Agregiranjem jedinica vremena, empirijski rezultati predstavljaju srednjoročnu dinamiku korigiranu za kratkoročne fluktuacije. Konačan skup podataka je neuravnotežen, s brojem promatranja koji varira od 107 do 125, ovisno o razlikama u duljini vremenskih serija varijabli.

Ostale kontrolne varijable su realna produktivnost rada, stopa nezaposlenosti, učinkovitost vlade, vanjskotrgovinska otvorenost te stopa neto migracije. Vanjskotrgovinska otvorenost je izražena kao postotak sume izvoza i uvoza u BDP-u te predstavlja utjecaj međunarodne trgovine na ekonomiju neke zemlje. Rodrik (1998.) ističe pozitivnu korelaciju vanjskotrgovinske otvorenosti i 
udjela državne potrošnje u ekonomiji, budući da državna potrošnja smanjuje eksterni rizik ekonomije.

Ekonomske odrednice fiskalnih varijabli su uključene kroz realnu produktivnost rada po osobi i stopu nezaposlenosti. Realna produktivnost rada je mjerena kao indeks s baznom 2010. godinom, dok je stopa nezaposlenosti definirana kao udio nezaposlenih u radnoj snazi i izražena u postotku. Stopa neto migracije je udio razlike između broja imigranata i emigranata u prosječnom broju stanovnika države u danoj godini. Izražena je u postotnim bodovima i s pozitivnim predznakom u slučaju neto priljeva stanovnika u zemlju.

Institucionalne razlike između širokog spektra zemalja su kontrolirane putem procjene učinkovitosti vlade, koja je jedna od šest dimenzija u World Governance Indicatoru (WGI) dostupnom u Data Banku (World Bank, 2016.). Dimenzija agregira percepcije kvalitete civilnih i javnih usluga te razinu autonomije vlade od političkih pritisaka, te pokazuje kvalitetu kreiranja politika i vjerodostojnost njihove primjene. Procjene predstavljaju ocjenu zemlje u sveukupnom WGI-u mjerenu jedinicama standardne normalne distribucije u rasponu od -2,5 do 2,5.

\section{TABLICA 1.}

Deskriptivna statistika

\begin{tabular}{lrrrrr} 
Varijabla & Aritm. sredina & St. dev. & Min. & Max. & Broj opažanja \\
\hline Proračunski rashodi & 45,13 & 6,43 & 32,60 & 60,35 & 121 \\
\hline Izdatci za zdravstvo & 5,75 & 1,60 & 1,73 & 8,625 & 121 \\
\hline Izdatci za mirovine & 7,89 & 2,51 & 2,60 & 13,75 & 107 \\
\hline Izdatci za socijalnu zaštitu & 16,12 & 4,24 & 7,60 & 24,75 & 121 \\
\hline Proračunski prihodi & 42,17 & 6,63 & 29,90 & 57,65 & 124 \\
\hline KDOS & 23,24 & 3,66 & 15,95 & 32,28 & 124 \\
\hline KDOM & 25,38 & 3,73 & 19,08 & 37,93 & 124 \\
\hline Realna produktivnost rada & 91,42 & 13,30 & 47,85 & 109,25 & 123 \\
\hline Stopa nezaposlenosti & 9,16 & 3,77 & 3,68 & 24,20 & 120 \\
\hline Učinkovitost vlade & 1,15 & 0,66 & $-0,62$ & 2,25 & 125 \\
\hline Vanjskotrgovinska otvorenost & 99,24 & 37,47 & 45,19 & 209,08 & 125 \\
\hline Stopa neto migracije & 1,14 & 4,89 & $-11,78$ & 20,55 & 125 \\
\hline
\end{tabular}

Izvor: autor, World Bank (2016.), Europska komisija (2015., 2016.).

Sve varijable, osim vanjskotrgovinske otvorenosti i učinkovitosti vlade, su preuzete iz Eurostata (Europska komisija, 2016.). Vanjskotrgovinska otvorenost i učinkovitost vlade su dostupni na World Bank (2016.). U daljnjoj analizi, većina varijabli prikazuje se u postotnim bodovima radi lakšeg tumačenja standardiziranih koeficijenata, budući da nema smisla logaritmirati postotke. Realna produktivnost rada i procjene učinkovitosti vlade su kasnije pretvorene u prirodne logaritme. Sažetak deskriptivne statistike varijabli dostupan je u tablici 1.

\subsection{Metodologija}

Budući da je sadašnja vrijednost proračunskih prihoda i rashoda u velikoj mjeri uvjetovana vrijednošću iz prošlog razdoblja, u istraživanju se umjesto statičkog koristi dinamički model. Relativna stabilnost većih kategorija proračunskih rashoda i prihoda uzrokuje perzistentnost fiskalnih varijabli. Primjerice, mala je vjerojatnost da će se izdatci za mirovine i zdravstvo drastično mijenjati u kratkom i srednjem roku. Prihodi od poreza na dohodak i PDV-a ovise neposredno o 
plaćama i ukupnoj ekonomskoj aktivnosti koji su empirijski dokazano perzistentni. Koristeći statički model, zanemaruje se informacija iz lagirane vrijednosti zavisne varijable, a dinamički model omogućava i modeliranje mehanizma parcijalne prilagodbe. Štoviše, uključivanje lagirane vrijednosti zavisne varijable ključno je za dobivanje konzistentnih procjena ostalih parametara iako autoregresivni koeficijent nije presudan (Bond, 2002.). Linearni dinamički model može se izraziti kao:

$$
y_{i, t}=\mu+\gamma y_{i, t-1}+\beta x_{i, t}+\alpha_{i}+\varepsilon_{i, t}
$$

gdje $i$ označava broj svakog opažanja $(\mathrm{i}=1,2, \ldots, \mathrm{N})$, a $t$ vremenska razdoblja $(\mathrm{t}=1,2, \ldots \mathrm{T})$. Vektori $y \mathrm{i}$ $x$ predstavljaju zavisne i nezavisne varijable, a $\beta$ je parametar koji nas zanima. Pretpostavlja se da su greške relacije $\varepsilon$ identično i nezavisno distribuirane kroz vrijeme i zemlje s aritmetičkom sredinom 0 i konstantnom varijancom. Parametri $\alpha_{i}$ su neopaženi vremenski nepromjenjiv učinak (specifičan za svaku zemlju) koji dopušta heterogenost među državama. Budući da je lagirana vrijednost zavisne varijable $y_{i, t-1}$ autokorelirana s $\alpha_{i}$, OLS procjenitelj je nekonzistentan i pristran čak i kada $N$ teži beskonačnosti, a $T$ je fiksan (Nickell, 1981.). Derivirajući jednadžbu, parametri $\alpha_{i}$ se uklanjaju iz jednadžbe što daje:

$$
y_{i, t}-y_{i, t-1}=\gamma\left(y_{i, t-1}-y_{i, t-2}\right)+\beta\left(x_{i, t}-x_{i, t-1}\right)+\left(\varepsilon_{i, t}-\varepsilon_{i, t-1}\right)
$$

Međutim, OLS metoda i dalje daje nekonzistentne procjene, jer su autoregresivni član i greške relacije, koje su sada proces pomičnih prosjeka prvog reda, korelirani kroz $y_{i, t-1}$ i $\varepsilon_{i, t-1}$. Anderson i Hsiao (1981.) su prvi predložili metodu procjene za dinamičke modele, gdje je član $\left(y_{i, t-1}-y_{i, t-2}\right)$ instrumentiran pomoću drugog laga u razinama $\left(y_{i, t-2}\right)$ ili druge diferencije zavisne varijable $\left(y_{i, t-2}-y_{i, t-3}\right)$. Korištenje drugog laga u razinama ima prednost pred diferenciranjem s obzirom da zahtijeva samo dva, dok je za diferencije potrebno najmanje tri razdoblja. Nadalje, Arellano (1989.) pokazuje da je bolje koristiti lagirane vrijednosti u razinama budući da ne uzrokuju problem singularnosti i rezultiraju manjom varijancom vrijednosti parametara.

U ovom istraživanju se primjenjuje procjenitelj generalizirane metode momenata (GMM), predstavljen u Holtz-Eakin et al. (1988.), a kasnije populariziran i poboljšan u Arellano i Bond (1991.), Arellano i Bover (1995.), te Blundell i Bond (1998.). Ovi procjenitelji su dizajnirani za dinamičke modele sa skupom podataka gdje je $T$ fiksan, a $N$ teži beskonačnosti, te su također pogodni za rješavanje problema endogenosti objašnjavajućih varijabli. Arellano i Bond (1991.) smatraju kako je diferencijski GMM procjenitelj efikasniji od Anderson-Hsiao procjenitelja, jer uvodi dodatna ograničenja kovarijanci regresora i grešaka relacije. Važno je naglasiti početnu pretpostavku o nepostojanju serijske korelacije grešaka relacije. Za prikaz GMM procjenitelja, promotrimo jednadžbu (2) u t=3 kao da je prvo razdoblje:

$$
y_{i, t-3}-y_{i, t-2}=\gamma\left(y_{i, t-2}-y_{i, t-1}\right)+\beta\left(x_{i, t-3}-x_{i, t-2}\right)+\left(\varepsilon_{i, t-3}-\varepsilon_{i, t-2}\right)
$$

gdje je $y_{i 1}$ prikladan instrument budući da je koreliran s $\left(y_{i, t-2}-y_{i, t-1}\right)$, no nije povezan s $\left(\varepsilon_{i, t-3}-\right.$ $\left.\varepsilon_{i, t-2}\right)$. Slijedeći istu logiku za razdoblje $\mathrm{t}=4$, mogu se kao instrumenti koristiti i $y_{i, 2}$ i $y_{i, 1}$. Ako se dodatno proširi spektar, primjećuje se da su u $T$, svi prikladni instrumenti za $\left(y_{i, t-2}-y_{i, t-1}\right)$ lagirane vrijednosti zavisne varijable u razinama $\left(y_{i 1}, y_{i 2}, \ldots y_{, T-2}\right)$.

U ovom radu se koristi sistemski GMM procjenitelj koji su razvili Arellano i Bover (1995.) te Blundell i Bond (1998.) koji je efikasniji od diferencijskog GMM procjenitelja, budući da su lagirane 
vrijednosti loši instrumenti za diferencije u diferencijskom GMM procjenitelju ako su varijable visokoperzistentne. Sistemski GMM procjenitelj nameće dodatna ograničenja početnim uvjetima, što dozvoljava uvođenje više momenata. Na kraju, to stvara sustav dviju jednadžbi - jednadžbu u razinama gdje su lagirane diferencije prikladni instrumenti te jednadžbu u prvim diferencijama s lagiranim razinama kao instrumentima.

Nadalje, umjesto dvofaznog, odabran je jednofazni sistemski GMM, jer su asimptotske standarde greške dvofaznog sistemskog GMM procjenitelja pristrane na niže u slučaju heteroskedastičnosti prostornih jedinica ili nenormalnosti (Blundell i Bond, 1998.). Iako je Windmeijer (2005.) predložio korekciju varijance koja rezultira preciznijim rezultatima, Monte Carlo simulacije pokazuju malo povećanje efikasnosti prilikom korištenja dvofaznog sistemskog GMM-a umjesto jednofazne verzije (Bond et al., 2001.; i Soto, 2009.). Također, u rezultatima su predstavljene robusne standardne pogreške koje su konzistentne u slučaju heteroskedastičnosti i autokorelacije unutar panela. Konačna specifikacija dinamičkog modela procijenjenog jednofaznim sistemskim GMM procjeniteljem će biti podvrgnuta dijagnostičkim testovima.

Arellano i Bond (1991.) predložili su m1 i m2 statističke testove autokorelacije grešaka relacije prvog i drugog reda. Očekuje se prisutnost autokorelacije prvog reda u greškama relacije, no GMM procjenitelj je konzistentan ako nema autokorelacije drugog reda u diferenciranoj jednadžbi. Posljedično, model je prikladno specificiran ako je nulta hipoteza odbačena za m1, te ne može biti odbačena za m2.

S obzirom da Sargan (1958.) test nije robustan u slučaju heteroskedastičnosti, Hansenov (1982.) Jtest procjenjuje valjanost instrumenata. Ako Hansenov test ukazuje na nemogućnost odbacivanja nulte hipoteze, momenti su prikladni te je zadovoljena ključna pretpostavka GMM-a - egzogenost svih instrumenata. Međutim, Hansenov test slabi s porastom broja momenata, što stvara problem proliferacije instrumenata koji će se detaljnije objasniti u sljedećem potpoglavlju.

\subsection{EMPIRIJSKI MODEL I REZULTATI}

Kako bi se istražio utjecaj starenja stanovništva na fiskalne varijable, konstruiran je empirijski model sličan onome u Callen et al. (2004.) i Yoon et al. (2014.). Specifikacija modela je:

$$
Y_{i, t}=\alpha_{i}+\gamma Y_{i, t-1}+\beta \operatorname{Demo}_{i, t}+\delta Z_{i, t}+\varepsilon_{i, t}
$$

gdje $Y$ predstavlja jednu od fiskalnih varijabli i njenu lagiranu vrijednost, Demo je skup demografskih varijabli, a $Z$ čine kontrolne varijable. Varijabla $\varepsilon$ su greške relacije, za koje se pretpostavlja da su nezavisno i identično raspoređene uz prosječnu vrijednost 0 i konstantnu varijancu. Indeksi $i$ i $t$ označavaju državu i vremensko razdoblje. Sve varijable su izražene u postotcima, osim produktivnosti rada i učinkovitosti vlade koje su logaritmirane.

Uključivanje lagirane vrijednosti zavisne varijable omogućuje razlikovanje srednjoročnih i dugoročnih učinaka, i konvergenciju udjela fiskalnih varijabli u BDP-u između zemalja. Raspisivanje jednadžbe (4) rezultira s:

$$
\Delta Y_{i, t}=\alpha_{i}+(\gamma-1) Y_{i, t-1}+\beta \operatorname{Demo}_{i, t}+\delta Z_{i, t}+\varepsilon_{i, t}
$$

U jednadžbi (5), autoregresivni koeficijent omogućava uvjetnu konvergenciju te kad je vrijednost manja od jedan, potvrđuje da zemlje bliže ravnotežnoj vrijednost razine proračunskih rashoda 
imaju manje stope rasta. U svim empirijskim modelima koeficijent je manji od jedan čime se potvrđuje uvjetna konvergencija. Također, u jednadžbi (5) je moguće razlikovati srednjoročni učinak koji se ogleda u koeficijentu $\beta$, i dugoročni koji se izračunava kao $\beta /(1-\gamma)$ što implicira da veći autogresivni koeficijent povećava dugoročni utjecaj nezavisne na zavisnu varijablu.

Procjenjujući dinamički model koristeći sistemski GMM procjenitelj, važno je obratiti pozornost na endogenost regresora, jer loša specifikacija dovodi do pristranih i nekonzistentnih procjena. Primjerice, autoregresivni član je nužno unaprijed određen zbog koreliranosti s greškama relacije. Preodređenost implicira da sadašnja ostvarenja grešaka relacije nisu korelirana prijašnjim i sadašnjim vrijednostima varijable, ali mogu biti s budućim ostvarenjima. U slučaju predodređenosti varijable, prikladni instrumenti za diferencijsku jednadžbu su razine u vremenu t-1 nadalje, dok su za jednadžbu u razinama prikladni instrumenti diferencije u razdoblju $t$.

Osim autoregresivnog člana, sve objašnjavajuće varijable su tretirane kao endogene. Zbog toga, prikladni instrumenti za jednadžbu u diferencijama su vrijednosti u razinama datirane t- 2 i nadalje, dok su diferencije u t-1 valjani instrumenti za jednadžbu u razinama. $S$ obzirom da je jedinica vremena u skupu podataka četverogodišnji prosjek, razumno je pretpostaviti obrnutu uzročnost fiskalnih i ostalih varijabli. I dok tretiranje ekonomskih kontrolnih varijabli endogenima nije predmet rasprave, budući da simultanost postoji u kraćem vremenu od četiri godine, posebna pozornost posvećena je opravdavanju endogenizacije demografskih varijabli u modelu.

Većina literature o utjecaju demografskih na ekonomske varijable smatra koeficijente dobne ovisnosti egzogenima. Ako se vremenska dimenzija sastoji od godina ili kvartala, ta pretpostavka bi mogla biti opravdana, no u srednjoročnom okviru može dovesti do nepouzdanih rezultata, što će se argumentirati primjerima.

Prvo, vlada odluči povećati stopu nataliteta te primijeni poticajne mjere koje utječu na povećanje izdataka za socijalnu zaštitu (točnije naknada za obitelj i djecu) ili rast rashoda za javno obrazovanje. Posljedično, parovi koji u suprotnom ne bi odlučili imati djecu, zbog relativnog smanjenja troška uzdržavanja djece, mijenjaju mišljenje. I dok te mjere vjerojatno neće povećati natalitet u prvoj ili drugoj, rezultati su mogući u trećoj i četvrtoj godini, što ulazi u četverogodišnji interval korišten u istraživanju.

Drugo, neto migracija utječe na oba koeficijenta dobne ovisnosti (KDOS i KDOM). Ako, zbog ekonomskih ili političkih razloga, dođe do neto odljeva stanovnika, većinom u fertilnoj dobi, smanjuju se oba koeficijenta dobne ovisnosti u zemlji polazištu, budući da relativna veličina starije i mlađe populacije raste, a prisutne su i posljedične promjene u zemlji odredišta.

Endogenost demografskih varijabli istaknuo je već Klein (1990.) tvrdeći kako se, u kratkoročnim cikličkim modelima, demografske varijable mogu ugrubo smatrati egzogenima, no osim toga je to loša pretpostavka. Također je naglasio potrebu za endogeniziranjem demografskih varijabli u daljnjim istraživanjima. Nažalost, većina dosadašnjih empirijskih istraživanja nije slijedila ovu preporuku.

Dobro je poznato kako diferencijski i sistemski GMM procjenitelji stvaraju instrumente koji mogu prekomjerno specificirati model. Posljedično, procijenjeni koeficijenti su pristrani u smjeru procjenitelja fiksnih učinaka i združenog OLS-a (Roodman, 2009.). Jedan od pokazatelja proliferacije instrumenata je savršena p-vrijednost 1 za Hansenov test. Sve procjene su donesene koristeći ekonometrijski program Stata 14.1 primjenom naredbe xtabond2 (Roodman, 2009.). Kako 
bi se riješio problem proliferacije instrumenata, $\mathrm{u}$ radu se koristi naredba collapse koja smanjuje broj momenata, što rezultira jednim instrumentom za svaki lag i nulom kao zamjenom za nedostajuću vrijednost.

\section{TABLICA 2.}

Procjena dinamičkog modela za mirovinske izdatke

\begin{tabular}{|c|c|c|c|}
\hline & Fiksni učinci & Združeni OLS & Sistemski GMM \\
\hline \multirow[t]{2}{*}{ Lagirana vrijednost zavisne varijable } & $0,521^{* * *}$ & $0,908^{* * *}$ & $0,835^{* * *}$ \\
\hline & $(0,099)$ & $(0,072)$ & $(0,157)$ \\
\hline \multirow[t]{2}{*}{ Koeficijent dobne ovisnosti starih } & $0,277^{* * *}$ & 0,049 & $0,174^{* * *}$ \\
\hline & $(0,052)$ & $(0,048)$ & $(0,050)$ \\
\hline \multirow[t]{2}{*}{ Koeficijent dobne ovisnost mladih } & 0,009 & 0,015 & 0,103 \\
\hline & $(0,060)$ & $(0,058)$ & $(0,064)$ \\
\hline \multirow[t]{2}{*}{ Ln (učinkovitost vlade) } & $-0,902^{* *}$ & $-0,263$ & $-0,182$ \\
\hline & $(0,351)$ & $(0,286)$ & $(0,488)$ \\
\hline \multirow[t]{2}{*}{ Ln (realna produktivnost rada) } & 1,755 & $-0,319$ & 2,381 \\
\hline & $(1,435)$ & $(3,336)$ & $(2,100)$ \\
\hline \multirow[t]{2}{*}{ Nezaposlenost } & $0,107 * * *$ & $-0,026$ & $0,093 * * *$ \\
\hline & $(0,028)$ & $(0,062)$ & $(0,034)$ \\
\hline \multirow[t]{2}{*}{ Vanjskotrgovinska otvorenost } & $-0,009$ & $-0,004$ & 0,003 \\
\hline & $(0,007)$ & $(0,005)$ & $(0,009)$ \\
\hline \multirow[t]{2}{*}{ Neto migracija } & $-0,016$ & 0,016 & $0,046^{* *}$ \\
\hline & $(0,019)$ & $(0,037)$ & $(0,021)$ \\
\hline \multirow[t]{2}{*}{ Konstantni član } & $-10,715$ & 1,613 & $-17,140 *$ \\
\hline & $(6,903)$ & $(15,131)$ & $(9,205)$ \\
\hline Broj opažanja & 80 & 80 & 80 \\
\hline Grupe & 24 & 24 & 24 \\
\hline $\mathrm{R}^{2}$ & 0,742 & 0,909 & - \\
\hline Hausman test & $27,62^{* * *}$ & - & - \\
\hline Instrumenti & - & - & 32 \\
\hline $\mathrm{m} 1$ test & - & - & 0,020 \\
\hline $\mathrm{m} 2$ test & - & - & 0,472 \\
\hline Hansen test & - & - & 0,945 \\
\hline
\end{tabular}

Bilješke: ${ }^{* * *},{ }^{* *} i *$ predstavljaju odbacivanje nulte hipoteze pri razini signifikantnosti 0,01; 0,05 i 0,1. Robustne standardne greške su u zagradama. $R^{2}$ je koeficijent determinacije. Broj opažanja i grupa je prikazana za sve procjenitelje, uz dodatak broja instrumenata za sistemski GMM. P-vrijednosti $m 1$ i $m 2$ testa autokorelacije prvog i drugog reda grešaka relacije su prikazane, kao i p-vrijednost Hansenovog testa.

Izvor: autor.

Prije prelaska na empirijske rezultate, treba naglasiti kako bi oni mogli ovisiti i o korištenoj ekonometrijskoj tehnici. Nagarajan et al. (2016.) su proveli anketu teorijskih i empirijskih studija koje istražuju utjecaj demografskog starenja na ekonomski rast, s javnim financijama kao jednim od posrednika. Prema njihovim rezultatima, najkorištenije ekonometrijske metode poput OLS-a i simulacija će vjerojatno pokazati negativnu vezu. S druge strane, primjena dinamičkog GMM-a i ostalih metoda će vjerojatno pokazati pozitivan ili nesignifikantan učinak. Rezultati su predstavljeni u tablicama 2, 3, 4, 5 i 6. Procjenitelj fiksnih učinaka izvodi procjene autoregresivnog parametra pristrane na niže, a OLS na više. Konzistentne procjene autoregresivnog člana u dinamičkim modelima procijenjenima pomoću sistemskog GMM-a bi se trebale nalaziti između 
fiksnih učinaka i OLS-a te se stoga uključuju i ti rezultati. Hausmanov test provjerava prikladnost procjenitelja slučajnih učinaka. Ako je nulta hipoteza odbačena, kao u svim modelima ovog istraživanja, procjenitelj fiksnih učinaka je prikladniji. Glavni rezultati su dobiveni koristeći jednofazni sistemski GMM procjenitelj, te će se samo oni interpretirati.

Procjena dinamičkog modela za mirovinske izdatke nalazi se u tablici 2. Relativno velika vrijednost (blizu 1) autoregresivnog parametra ukazuje na snažnu perzistentnost mirovinskih izdataka. Među ostalim regresorima, procjene parametara uz KDOS i nezaposlenost su značajne na razini od 0,01, dok je standardizirani koeficijent uz migracije značajan na razini 0,05 .

Očekivano, KDOS je najvažnija odrednica mirovinskih izdataka u srednjem i dugom roku. U srednjem roku, povećanje KDOS-a za jedan postotni bod podiže izdatke za 0,17 postotnih bodova, a u dugom roku čak do 1,04 . Nezaposlenost utječe na porast mirovinskih izdataka, jer viša stopa nezaposlenosti potiče raniji odlazak u mirovinu, što se primarno odnosi na najstariju populaciju nezaposlenih s relativno manjom vjerojatnošću pronalaska posla. U dugom roku, procijenjeni koeficijent uz nezaposlenost je 0,55. Također, povećanje stope neto migracije uzrokuje porast mirovinskih izdataka za 0,046 postotna boda.

\section{TABLICA 3.}

Procjena dinamičkog modela za izdatke za socijalnu zaštitu

Fiksni učinci

\begin{tabular}{|c|c|c|c|}
\hline & Fiksni učinci & Združeni OLS & Sistemski GMM \\
\hline \multirow{2}{*}{ Lagirana vrijednost zavisne varijable } & 0,138 & $0,937^{* * *}$ & $0,721 * * *$ \\
\hline & $(0,110)$ & $(0,040)$ & $(0,091)$ \\
\hline \multirow[t]{2}{*}{ Koeficijent dobne ovisnosti starih } & $0,192^{* *}$ & 0,035 & $0,227^{* *}$ \\
\hline & $(0,094)$ & $(0,055)$ & $(0,098)$ \\
\hline \multirow[t]{2}{*}{ Koeficijent dobne ovisnost mladih } & $-0,022$ & 0,065 & 0,121 \\
\hline & $(0,130)$ & $(0,059)$ & $(0,156)$ \\
\hline \multirow[t]{2}{*}{ Ln (učinkovitost vlade) } & $-1,622^{* *}$ & $-0,610^{*}$ & 0,539 \\
\hline & $(0,690)$ & $(0,341)$ & $(1,020)$ \\
\hline \multirow[t]{2}{*}{ Ln (realna produktivnost rada) } & 2,513 & $-6,611$ & 4,206 \\
\hline & $(2,749)$ & $(4,210)$ & $(3,353)$ \\
\hline \multirow[t]{2}{*}{ Nezaposlenost } & $0,228^{* * *}$ & $-0,041$ & $0,143^{* *}$ \\
\hline & $(0,062)$ & $(0,060)$ & $(0,057)$ \\
\hline \multirow[t]{2}{*}{ Vanjskotrgovinska otvorenost } & $-0,003$ & $-0,004$ & 0,006 \\
\hline & $(0,015)$ & $(0,005)$ & $(0,013)$ \\
\hline \multirow[t]{2}{*}{ Neto migracija } & $-0,047$ & $0,124 * *$ & $0,102^{*}$ \\
\hline & $(0,043)$ & $(0,052)$ & $(0,060)$ \\
\hline \multirow[t]{2}{*}{ Konstantni član } & $-2,898$ & 29,624 & $-24,856$ \\
\hline & $(13,710)$ & $(19,239)$ & $(16,283)$ \\
\hline Broj opažanja & 91 & 91 & 91 \\
\hline Grupe & 24 & 24 & 24 \\
\hline $\mathrm{R}^{2}$ & 0,590 & 0,805 & - \\
\hline Hausman test & $57,79^{* * *}$ & - & - \\
\hline Instrumenti & - & - & 24 \\
\hline $\mathrm{m} 1$ test & - & - & 0,047 \\
\hline $\mathrm{m} 2$ test & - & - & 0,201 \\
\hline Hansen test & - & - & 0,425 \\
\hline
\end{tabular}

Bilješke: vidjeti bilješke u tablici 2.

Izvor: autor. 
Rezultati dinamičkog modela izdataka za socijalnu zaštitu nalaze se u tablici 3. Kao u modelu mirovinskih izdataka, isti regresori - nezaposlenost, neto migracija i KDOS - su robusni i pozitivno utječu na razinu izdataka za socijalnu zaštitu. S obzirom na manju perzistentnost izdataka za socijalnu zaštitu, dugoročni utjecaj značajnih varijabli je relativno manji.

Srednjoročni utjecaj KDOS-a je relativno veći u usporedbi s onim iz tablice 2, jer izdatci za socijalnu zaštitu sadrže više kategorija dostupnih starijoj populaciji. Jednako zaključivanje je primjenjivo za neto migraciju, budući da migranti imaju relativno veći broj dostupnih beneficija. Pozitivan utjecaj starije populacije na rast izdataka za socijalnu zaštitu potvrđuje rezultate do kojih su došli Lusky i Weinblatt (1998.) te Labrador i Angona (2003.). Promjene u udjelu mlade populacije ne utječu značajno na razinu izdataka za socijalnu zaštitu.

\section{TABLICA 4.}

Procjena dinamičkog modela za izdatke za zdravstvenu skrb

\begin{tabular}{|c|c|c|c|}
\hline & Fiksni učinci & Združeni OLS & Sistemski GMM \\
\hline \multirow[t]{2}{*}{ Lagirana vrijednost zavisne varijable } & $0,551^{* * *}$ & $1,041^{* * *}$ & $0,858^{* * *}$ \\
\hline & $(0,120)$ & $(0,054)$ & $(0,127)$ \\
\hline \multirow{2}{*}{ Koeficijent dobne ovisnosti starih } & 0,049 & 0,005 & 0,046 \\
\hline & $(0,049)$ & $(0,021)$ & $(0,038)$ \\
\hline \multirow[t]{2}{*}{ Koeficijent dobne ovisnost mladih } & $-0,018$ & 0,038* & $0,132 * *$ \\
\hline & $(0,059)$ & $(0,021)$ & $(0,060)$ \\
\hline \multirow[t]{2}{*}{ Ln (učinkovitost vlade) } & $-0,388$ & $-0,094$ & $-0,466$ \\
\hline & $(0,322)$ & $(0,118)$ & $(0,653)$ \\
\hline \multirow[t]{2}{*}{ Ln (realna produktivnost rada) } & 0,242 & 0,708 & $2,939 * *$ \\
\hline & $(1,256)$ & $(1,574)$ & $(1,468)$ \\
\hline \multirow[t]{2}{*}{ Nezaposlenost } & 0,015 & $-0,029$ & $-0,031$ \\
\hline & $(0,028)$ & $(0,022)$ & $(0,045)$ \\
\hline \multirow{2}{*}{ Vanjskotrgovinska otvorenost } & 0,001 & $-0,0002$ & $-0,005$ \\
\hline & $(0,007)$ & $(0,002)$ & $(0,005)$ \\
\hline \multirow{2}{*}{ Neto migracija } & 0,001 & $-0,009$ & $-0,008$ \\
\hline & $(0,020)$ & $(0,019)$ & $(0,026)$ \\
\hline \multirow[t]{2}{*}{ Konstantni član } & 0,806 & $-3,926$ & $-15,722^{* *}$ \\
\hline & $(6,276)$ & $(7,194)$ & $(7,137)$ \\
\hline Broj opažanja & 91 & 91 & 91 \\
\hline Grupe & 24 & 24 & 24 \\
\hline $\mathrm{R}^{2}$ & 0,713 & 0,919 & - \\
\hline Hausman test & $18,68^{* *}$ & - & - \\
\hline Instrumenti & - & - & 24 \\
\hline $\mathrm{m} 1$ & - & - & 0,051 \\
\hline $\mathrm{m} 2$ & - & - & 0,725 \\
\hline Hansen test & - & - & 0,322 \\
\hline
\end{tabular}

Bilješke: vidjeti bilješke u tablici 2.

Izvor: autor.

Rezultati modela za izdatke za zdravstvenu skrb mogu se vidjeti u tablici 4 , a njihove značajne odrednice su realna produktivnost rada i KDOM. Povećanje produktivnosti od 1\% dovodi do prosječnog rasta izdataka za zdravstvo od 2,94 postotna boda. Dominantan utjecaj produktivnosti, a ne demografskih varijabli, je u skladu s rezultatima prijašnjih istraživanja koja tvrde da je 
produktivnost glavna odrednica izdataka za zdravstvo. Povećanje KDOM-a za 1 postotni bod dovodi do rasta izdataka za zdravstvo od 0,13 postotna boda, što potvrđuje U krivulju koja predstavlja vezu između izdataka za zdravstvo i dobnih skupina, jer su izdaci najveći za mlađe dobne kategorije. Pomalo neočekivano, KDOS nema značajan utjecaj na razinu izdataka za zdravstvo.

\section{TABLICA 5.}

Procjena dinamičkog modela za ukupne proračunske rashode

\begin{tabular}{|c|c|c|c|}
\hline & Fiksni učinci & Združeni OLS & Sistemski GMM \\
\hline \multirow[t]{2}{*}{ Lagirana vrijednost zavisne varijable } & 0,011 & $0,850 * * *$ & $0,519 * * *$ \\
\hline & $(0,112)$ & $(0,051)$ & $(0,120)$ \\
\hline \multirow[t]{2}{*}{ Koeficijent dobne ovisnosti starih } & $0,390 *$ & 0,026 & $0,501^{* *}$ \\
\hline & $(0,217)$ & $(0,097)$ & $(0,208)$ \\
\hline \multirow[t]{2}{*}{ Koeficijent dobne ovisnost mladih } & $-0,062$ & 0,099 & 0,034 \\
\hline & $(0,312)$ & $(0,102)$ & $(0,305)$ \\
\hline \multirow[t]{2}{*}{ Ln (učinkovitost vlade) } & $-3,607^{*}$ & $-0,662$ & 1,967 \\
\hline & $(1,606)$ & $(0,572)$ & $(2,251)$ \\
\hline \multirow[t]{2}{*}{ Ln (realna produktivnost rada) } & 1,986 & 10,344 & 5,236 \\
\hline & $(6,359)$ & $(7,337)$ & $(6,188)$ \\
\hline \multirow[t]{2}{*}{ Nezaposlenost } & $0,379 * *$ & $-0,122$ & $0,315^{* *}$ \\
\hline & $(0,143)$ & $(0,103)$ & $(0,124)$ \\
\hline \multirow[t]{2}{*}{ Vanjskotrgovinska otvorenost } & $-0,019$ & $-0,003$ & 0,004 \\
\hline & $(0,035)$ & $(0,009)$ & $(0,028)$ \\
\hline \multirow[t]{2}{*}{ Neto migracija } & $-0,158$ & 0,049 & 0,319* \\
\hline & $(0,100)$ & $(0,089)$ & $(0,172)$ \\
\hline \multirow[t]{2}{*}{ Konstantni član } & 27,032 & $-41,838$ & $-18,788$ \\
\hline & $(31,747)$ & $(33,334)$ & $(31,378)$ \\
\hline Broj opažanja & 91 & 91 & 91 \\
\hline Grupe & 24 & 24 & 24 \\
\hline $\mathrm{R}^{2}$ & 0,434 & 0,750 & - \\
\hline Hausman test & $90,83^{* * *}$ & - & - \\
\hline Instrumenti & - & - & 31 \\
\hline $\mathrm{m} 1$ & - & - & 0,027 \\
\hline $\mathrm{m} 2$ & - & - & 0,370 \\
\hline Hansen test & - & - & 0,429 \\
\hline
\end{tabular}

Bilješke: vidjeti bilješke u tablici 2.

Izvor: autor.

Kao što je predočeno u tablici 5, karakteristike modela ukupnih proračunskih rashoda su slične modelima za mirovinske izdatke i izdatke za socijalnu zaštitu. Međutim, glavna razlika je stupanj perzistentnosti mjeren parametrom $\gamma$, koji je u ovom modelu najniži s procjenom od 0,5. Posljedično, dugoročni utjecaj relevantnih objašnjavajućih varijabli je relativno manji. Parametarska procjena KDOS-a je pozitivna i signifikantna pri razini od 0,05. U srednjem roku, povećanje KDOS-a od 1 postotnoga boda podiže ukupne proračunske rashode za 0,5 postotna boda.

Standardizirani koeficijenti za nezaposlenost i neto migraciju iznose 0,31 i 0,32 pri razini signifikantnosti od 0,05 i 0,1. S obzirom da su koeficijenti i prilično slični, država koja se suočava s neto emigracijom može poništiti utjecaj nezaposlenosti. Međutim, parametar uz KDOM nije signifikantan što implicira kako porast mlade populacije u odnosu na radno sposobnu ne utječe na 
ukupne proračunske rashode. Na sličan način nisu značajne ni vanjskotrgovinska otvorenost, produktivnost rada i učinkovitost vlade.

Rezultati dinamičkog modela za ukupne proračunske prihode nalaze se u tablici 6. Autoregresivni koeficijent od 0,76 je veći od autoregresivnog koeficijenta ukupnih proračunskih rashoda što ukazuje na relativno veći stupanj perzistentnosti. Utjecaj neto migracije i KDOS-a je pozitivan i signifikantan pri razini od 0,01 i 0,05. Porast starije populacije povećava ukupne proračunske prihode i rashode, no utjecaj je veći na rashode, što na kraju negativno utječe na proračunski deficit te potvrđuje rezultate iz Callen et al. (2004.) te Hondroyiannis i Papapetrou (2008.). Također, interpretacija rezultata za neto migraciju je vjerodostojna ako je ukupna populacija konstantna.

\section{TABLICA 6.}

Procjena dinamičkog modela za ukupne proračunske prihode

\begin{tabular}{|c|c|c|c|}
\hline & Fiksni učinci & Združeni OLS & Sistemski GMM \\
\hline \multirow[t]{2}{*}{ Lagirana vrijednost zavisne varijable } & $0,213^{* *}$ & $0,933^{* * *}$ & $0,757^{* * *}$ \\
\hline & $(0,102)$ & $(0,036)$ & $(0,037)$ \\
\hline \multirow[t]{2}{*}{ Koeficijent dobne ovisnosti starih } & $0,281^{* *}$ & 0,034 & $0,326^{* * *}$ \\
\hline & $(0,119)$ & $(0,082)$ & $(0,082)$ \\
\hline \multirow[t]{2}{*}{ Koeficijent dobne ovisnost mladih } & $-0,178$ & $-0,009$ & 0,134 \\
\hline & $(0,132)$ & $(0,080)$ & $(0,162)$ \\
\hline \multirow[t]{2}{*}{ Ln (učinkovitost vlade) } & 1,118 & $-0,520$ & 1,177 \\
\hline & $(0,893)$ & $(0,421)$ & $(0,936)$ \\
\hline \multirow[t]{2}{*}{ Ln (realna produktivnost rada) } & $-4,283$ & 2,071 & 4,277 \\
\hline & $(3,473)$ & $(5,777)$ & $(3,346)$ \\
\hline \multirow[t]{2}{*}{ Nezaposlenost } & $0,171 * *$ & $-0,171 * *$ & 0,012 \\
\hline & $(0,074)$ & $(0,075)$ & $(0,057)$ \\
\hline \multirow[t]{2}{*}{ Vanjskotrgovinska otvorenost } & 0,001 & $-0,005$ & 0,003 \\
\hline & $(0,019)$ & $(0,006)$ & $(0,015)$ \\
\hline \multirow{2}{*}{ Neto migracija } & 0,078 & 0,035 & $0,120^{* *}$ \\
\hline & $(0,054)$ & $(0,071)$ & $(0,050)$ \\
\hline \multirow[t]{2}{*}{ Konstantni član } & $48,781^{* * *}$ & $-5,143$ & $-20,824$ \\
\hline & $(18,402)$ & $(25,492)$ & $(16,669)$ \\
\hline Broj opažanja & 94 & 94 & 94 \\
\hline Grupe & 24 & 24 & 24 \\
\hline $\mathrm{R}^{2}$ & 0,671 & 0,930 & - \\
\hline Hausman test & $61,20^{* * *}$ & - & - \\
\hline Instrumenti & - & - & 32 \\
\hline $\mathrm{m} 1$ & - & - & 0,013 \\
\hline $\mathrm{m} 2$ & - & - & 0,828 \\
\hline Hansen test & - & - & 0,805 \\
\hline
\end{tabular}

Bilješke: vidjeti bilješke u tablici 2.

Izvor: autor. 


\section{ZAKLJUČAK}

Povećanje udjela starije populacije, produljenje očekivanog životnog vijeka i smanjenje stope fertiliteta su karakteristike starenja stanovništva. Demografske projekcije za EU od 2013. do 2060. predviđaju povećanje stope totalnog fertiliteta, ali ispod razine potrebne za zamjenu generacija, te značajno produljenje trajanja života muškaraca i žena. Posljedično, očekuje se prosječno povećanje koeficijenata dobne ovisnosti starih i mladih za 92,9\% i 13,2\%. Proračunske prognoze demografskog utjecaja predviđaju prosječno povećanje izdataka za zdravstvenu skrb u svim zemljama za 24,1\%, u odnosu na razinu iz 2013. S druge strane, pretpostavlja se neznatno povećanje mirovinskih izdataka, jer se glavni čimbenik njihovog rasta - povećanje KDOS-a poništava zakonskim reformama mirovinskih sustava.

Točan učinak starenja stanovništva na ekonomiju je predmet rasprave zbog nedostatka jedinstvenog stava o utjecaju na BDP po stanovniku, štednju i inflaciju. Prijašnja istraživanja fiskalnog utjecaja demografskih varijabli ukazuju na pozitivan učinak starenja stanovništva na rast proračunskih rashoda i negativan efekt na proračunski saldo. Ovaj rad doprinosi postojećoj literaturi endogeniziranjem demografskih varijabli omogućujući uzročnost s fiskalnim varijablama.

Skup podataka se sastoji od opažanja za 25 zemalja EU-a u razdoblju od 1995. do 2014. Radi analize srednjoročne dinamike, koriste se četverogodišnji prosjeci čime se dobiva pet vremenskih razdoblja. Analiziraju se odabrane kategorije proračunskih rashoda i njihova ukupna veličina te proračunski prihodi. Demografske varijable i set kontrolnih varijabli su regresori u modelima. U fokusu su istraživanja procjene koeficijenata dobne ovisnosti starih i mladih. Kontrolne varijable su stopa nezaposlenosti, realna produktivnost rada, procjena učinkovitosti vlade, vanjskotrgovinska otvorenost i stopa neto migracije. Svi regresori, osim lagirane vrijednosti zavisne varijable, se tretiraju endogenima čime su prikladni instrumenti vrijednosti u razinama datirane t-2 nadalje.

Najprikladnija metoda procjene dinamičkih modela za skupove podataka gdje je $T$ malen, a $N$ velik, je generalizirana metoda momenata (GMM), pa se u ovom radu koristi jednofazni sistemski GMM kojeg su za procjenu dinamičkih modela razvili Blundell i Bond (1998.). Konačni rezultati pokazuju standardne greške robusne na heteroskedastičnost unutar jedinica promatranja. Rezultati analize su podvrgnuti testiranju robusnosti ispitivanjem korelacije u rezidualima i valjanosti instrumenata.

Rezultati procjene utjecaja starenja stanovništva na proračunski saldo i mirovinske izdatke su u skladu s prijašnjom literaturom, ali su u suprotnosti s tezom prema kojoj određuje i izdatke za zdravstvenu skrb. Zaključno, starenje stanovništva povećava mirovinske izdatke i izdatke za socijalnu zaštitu. Kako je pozitivan učinak veći na rast proračunskih rashoda nego prihoda, povećanje starijeg stanovništva negativno utječe na proračunski saldo. S druge strane, povećanje mlade populacije je značajno i pozitivno utječe na rast samo u modelu izdataka za zdravstvenu skrb, ali puno manje od realne produktivnosti rada koja je njihova glavna odrednica. Kod kontrolnih varijabli, nezaposlenost i neto migracija povećavaju izdatke za socijalnu zaštitu, mirovinske izdatke kao njihovu sastavnicu, te ukupne proračunske rashode. Neto emigracija karakteristična za zemlje Srednje i Istočne Europe možda sama po sebi ne utječe negativno na proračunski saldo, s obzirom da smanjuje pritisak na izdatke za socijalnu zaštitu i mirovinske izdatke.

Vlasti bi tijekom određivanja srednjoročnih proračunskih okvira trebale razmišljati o demografskim prognozama. Empirijski rezultati ukazuju da su potrebne mjere koje će ublažavati 
učinke starenja stanovništva. To mogu biti aktivne politike zapošljavanja radi povećanja stope participacije radne snage i zaposlenosti, ili zakonske reforme koje povećavaju prag za ulazak u mirovinu strožim kriterijima i penalizacijom prijevremene mirovine, te poticajima za zaposlenje nakon dobi za ulazak u mirovinu. S metodološke strane, naglašava se potreba tretiranja demografskih varijabli u ekonomskim modelima endogenima, jer su uvjetovane sadašnjim ekonomskim čimbenicima, među ostalim javnim financijama. 


\section{REFERENCE}

1. Anderson, T. W. i Hsiao, C., 1981. Estimation of Dynamic Models with Error Components. Journal of the American Statistical Association, 76(375), str. 598-606. doi: 10.1080/01621459.1981.10477691

2. Arellano, M., 1989. A note on the Anderson-Hsiao estimator for panel data. Economic Letters, 31(4), str. 337-341. doi: 10.1016/0165-1765(89)90025-6

3. Arellano, M. i Bond, S., 1991. Some Tests of Specification for Panel Data: Monte Carlo Evidence and an Application to Employment Equations. The Review of Economic Studies, 58(2), str. $277-$ 297. doi: $10.2307 / 2297968$

4. Arellano, M. i Bover, 0., 1995. Another look at the instrumental variable estimation of errorcomponents models. Journal of Econometrics, 68(1), str. 29-51. doi: 10.1016/03044076(94)01642-D

5. Auerbach, A. J. i Kotlikoff, L. J., 1985. Simulating Alternative Social Security Responses to the Demographic Transition. National Tax Journal, 38(2), str. 153-168.

6. Auerbach, A. J. i Kotlikoff, L. J., 1987. Dynamic fiscal policy. Cambridge: Cambridge University Press.

7. Auerbach, A. J. [et al.], 1989. The Economic Dynamic of an Ageing Population: The Case of Four OECD Countries. OECD Economics Department Working Papers, Br. 62.

8. Blanchard, O. J., 1985. Debt, Deficits and Finite Horizon. The Journal of Political Economy, 93(2), str. 223-247. doi: 10.1086/261297

9. Bloom E., D., Canning, D. i Fink, G., 2011. Implications of Population Aging for Economic Growth. PGDA Working Paper, Br. 64.

10. Blundell, R. i Bond, S., 1998. Initial conditions and moment restrictions in dynamic panel data models. Journal of Econometrics, 87, str. 115-143.

11. Bond, S., 2002. Dynamic Panel Data Models: A Guide to Micro Data Methods and Practice. Cemmap working paper CWP09/02.

12. Bond, S., Hoeffler, A. i Temple, J., 2001. GMM Estimation of Empirical Growth Models. Economics Papers.

13. Börsch-Supan, A., Ludwig, A. i Winter, J., 2006. Ageing, Pension Reform and Capital Flows: A Multi-country Simulation Model. Economica, 73(292), str. 625-658. doi: 10.1111/j.14680335.2006.00526.x

14. Börsch-Supan, H., Hartl, K. i Ludwig, A., 2014. Aging in Europe: Reforms, International Diversification and Behavioral Reactions. Max Planck Institute for Social Law and Social Policy Discussion Paper, Br. 25.

15. Bullard, J., Garriga, C. i Waller, C. J., 2012. Demographics, Redistribution, and Optimal Inflation. Federal Reserve Bank of St. Louis Review, 94(6), str. 419-439.

16. Bussolo, M., Koettl, J. i Sinnott, E., 2015. Golden Aging: Prospects for Healthy, Active, and Prosperous Aging in Europe and Central Asia. doi: 10.1596/978-1-4648-0353-6

17. Callen, T., Batini, N. i Spatafora, N., 2004. How will demographic change affect the global economy. Chapter 3: an.

18. Chawla, M., Kawiorska, D. i Chelleraj, G., 1998. The Impact of Economic and Demographic Factors on Government Health Expenditures in Poland. International Health System Group, Working Paper, Br. 72.

19. Chen, D. H., 2004. Population Age structure and the budget deficit. World Bank Policy Research Working Paper, Br. 3435.

20. European Commission, 2015. The 2015 Ageing Report: Economic and budgetary projections for the 28 EU Member States (2013-2060). Dostupno na: <http://ec.europa.eu/economy_finance/publications/european_economy/2015/pdf/ee3_en.pdf>.

21. De la Croix, D., Pierrard, O. i Sneessens, H. R., 2013. Aging and pensions in general equilibrium: Labor market imperfections matter. Journal of Economic Dynamics and Control, 37(1), str. 104124. doi: 10.1016/j.jedc.2012.06.011

22. Di Matteo, L., 2005. The macro determinants of health expenditure in the United States and Canada: assessing the impact of income, age distribution and time. Health Policy, 71(1), str. 23 42. doi: 10.1016/j.healthpol.2004.05.007 
23. Di Matteo, L. i Di Matteo, R., 1998. Evidence on the determinants of Canadian provincial government health expenditures: 1965-1991. Journal of Health Economics, 17(2), str. 211-228. doi: 10.1016/S0167-6296(97)00020-9

24. Díaz-Giménez, J. i Díaz-Saavedra, J., 2009. Delaying retirement in Spain. Review of Economic Dynamics, 12(1), str. 147-167. doi: 10.1016/j.red.2008.06.001

25. Fougère, M. i Mérette, M., 1999. Population ageing and economic growth in seven OECD countries. Economic Modelling, 16(3), str. 411-427. doi: 10.1016/S0264-9993(99)00008-5

26. Hansen, L. P., 1982. Large Sample Properties of Generalized Method of Moments Estimators. Econometrica, 50(4), str. 1029-1054. doi: 10.2307/1912775

27. Heijdra, B. i Romp, W., 2009. Retirement, pensions and ageing. Journal of Public Economics, 93(3-4), str. 586-604. doi: 10.1016/j.jpubeco.2008.10.009

28. Holtz-Eakin, D., Newey, W. i Rosen, H. S., 1988. Estimating Vector Autoregressions with Panel Data. Econometrica, 56(6), str. 1371-1395. doi: 10.2307/1913103

29. Hondroyiannis, G. i Papapetrous, E., 2008. Do Demographic Changes Affect Fiscal Developments?. Public Finance Review, September, 28(5), str. 468-488.

30. Hviding, K. i Mérette, M., 1998. Macroeconomic Effects of Pension Reforms in The Context of Ageing Populations: Overlapping Generations Model Simulations for Seven OECD Countries. OECD Economics Department Working Papers, Br. 201.

31. Jimeno, J. F., Rojas, J. A. i Puente, S., 2008. Modelling the impact of aging on social security expenditures. Economic Modelling, 25(2), str. 201-224. doi: 10.1016/j.econmod.2007.04.015

32. Jones, C. I., 1995. R\&D-Based Models of Economic Growth. Journal of Political Economy,103(4), str. 759-784. doi: 10.1086/262002

33. Juselius, M. i Takáts, E., 2015. Can demography affect inflation and monetary policy?. Bank for International Settlements Working Papers, Br. 485.

34. Katagiri, M., Konishi, H. i Ueda, K., 2014. Aging and Deflation from a Fiscal Perspective. Federal Reserve Bank of Dallas, Working Paper, Br. 218.

35. King, P. i Jackson, H., 2000. Public Finance Implications of Population Aging. Department of Finance Working Paper, Br. 2000-08.

36. Klein, L. R., 1990. The Concept of Exogeniety in Econometrics. In: R. Carter, J. Dutta and A. Ullah, ur. Contributions to Econometric Theory and Application: Essays in Honour of A.L.Nagar. s.l.:Springer New York, str. 1-23.

37. Kudrna, G., Tran, C. i Woodland, A., 2015. The Dynamic Fiscal Effects of Demographic Shift: The Case of Australia. Economic Modelling, 50, str. 105-122.

38. Labrador, I. i Angona, F., 2003. Labrador, I. S., \& Angona, F. J. V. (2003). Fiscal illusion, fiscal consolidation and government expenditure composition in the OECD: a dynamic panel data approach. Universidad de Laguna.

39. Luski, I. i Weinblatt, J., 1998. A dynamic analysis of fiscal pressure and demographic transition. Applied Economics, 30(11), str. 1431-1442. doi: 10.1080/000368498324788

40. Martín, J. J. M., del Amo Gonzáleza, M. P. L. i García, M. D. C., 2011. Review of the literature on the determinants of healthcare expenditure. Applied Economics, 43(1), str. 19-46. doi: $10.1080 / 00036841003689754$

41. Miles, D., 1999. Modelling the Impact of Demographic Change upon the Economy. The Economic Journal, 109(452), str. 1-36. doi: 10.1111/1468-0297.00389

42. Nagarajan, N. [et al.], 2016. The impact of an ageing population on economic growth: an exploratory review of the main mechanisms. Analise Sociale, LI(218).

43. Nickell, S., 1981. Biases in Dynamic Models with Fixed Effects. Econometrica, 49(6), str. 14171426. doi: $10.2307 / 1911408$

44. Prettner, K., 1995. Population aging and endogenous economic growth. Journal of Population Economics, 26(2), str. 811-834. doi: 10.1007/s00148-012-0441-9

45. Prieto, D. C. i Lago-Peñas, S., 2010. Decomposing the determinants of health care expenditure: the case of Spain. The European Journal of Health Economics, 13(1), str. 19-27. doi: 10.1007/s10198-010-0276-9

46. Rodrik, D., 1998. Why Do More Open Economies Have Bigger Governments. Journal of Political Economy, 106(5), str. 997-1032. doi: 10.1086/250038 
47. Romer, P. M., 1990. Endogenous Techonological Change. Journal of Political Economy, 98(5), str. 71-102.

48. Roodman, D., 2009. A Note on the Theme of Too Many Instruments. Oxford Bulletin of Economics \& Statistics, 71(1), str. 135-158. doi: 10.1111/j.1468-0084.2008.00542.x

49. Roodman, D., 2009. How to do xtabond: An introduction to difference and system GMM in Stata. Stata Journal, 9(1), str. 86-136.

50. Sargan, J. D., 1958. The estimation of economic relationships using instrumental variables. Econometrica, 26(3), str. 393-415. doi: 10.2307/1907619

51. Shirakawa, M., 2012. Demographic Changes and Macroeconomic Performance: Japanese Experiences, s.l.: Opening Remark at 2012 BOJ-IMES Conference hosted by Institute for Monetary and Economic Studies, the Bank of Japan.

52. Soto, M., 2009. System GMM estimation. Barcelona Economics Working Paper Series, Br. 395.

53. Windmeijer, F., 2005. A finite sample correction for the variance of linear efficient two-step GMM estimators. Journal of Econometrics, 126(1), str. 25-51. doi: 10.1016/j.jeconom.2004.02.005

54. World Bank, 2016. Data Bank. Dostupno na: <http://databank.worldbank.org/data/home.aspx>.

55. Xu, K., Saksena, P. i Holly, A., 2011. The Determinants of Health Expenditure: A Country-Level Panel Data Analysis. World Health Organization Working Paper.

56. Yashiro, N., Oshio, T. i Matsuya, M., 1997. Macroeconomic and Fiscal Impacts of Japan's Aging Population with a Specific Reference to Pension Reforms. Discussion Paper, Br. 78. Tokyo: Economic Research Institute, Economic Planning Agency.

57. Yoon, J.-W., Kim, J. i Lee, J., 2014. Impact of Demographic Changes on Inflation and the Macroeconomy. IMF Working Paper 14/210. 